\title{
Entre Amazonas y Grifos. Viaje por las imágenes de frontera en el siglo IV a.C.*
}

\section{Amid Amazons and Griffins. A journey through frontier imagery in the IV century B.C.}

\author{
Margarita Moreno Conde \\ Paloma Cabrera Bonet \\ Museo Arqueológico Nacional
}

\section{RESUMEN}

La imagen de las Amazonas comienza a poblar los vasos griegos desde fines del siglo VII a.C. De naturaleza polisémica, encarnan la alteridad absoluta para el ideal ciudadano griego, pues representan todos los valores antitéticos: son mujeres, bárbaras, no domesticadas. A lo largo de los siglos se dotan de nuevos significados, especialmente en el siglo IV a.C., época de profundas mutaciones geopolíticas. La representación de la lucha por el control del oro entre Arimaspos, feroces guerreros de un solo ojo y Grifos, temibles seres híbridos que lo arrancan de la tierra y custodian, nace a fines del siglo vi a.C. pero será también en el siglo IV a.C. cuando se convierta en un tema predilecto de los pintores griegos, destinado a las áreas periféricas. Analizamos el área de distribución de los vasos decorados con ambos temas en los dos extremos del Mediterráneo y su significado. Amazonomaquias y Grifomaquias, imágenes de la frontera, parecen actuar como elementos indispensables en la construcción de la identidad griega.

\section{SUMMARY}

The Amazon imagery started population Greek vases at the end of the VII century B.C. Being of a polysemic nature, they personify the absolute otherness for the ideal Greek citizen, due to their representation of all the antithetical values: they are women, barbarian, undomesticated. Through the following centuries they are endowed with new meanings, especially in the IV century B.C., a time of profound geopolitical changes. The graphical representation of the struggle for the control of gold between Arimaspi, fierce one-eyed warriors, and Gryps, fearsome hybrid beings that extract it from the earth and guard it, starts towards the end of the VI century B.C., but it will also become a favourite theme of the Greek painters in the IV century B.C., mainly intended for the peripheral areas. We analyze the distribution area of vases decorated with both themes at both ends of the Mediterranean, and its meaning. Amazonomachy and Grypomachy, frontier imagery, seem to act as essential elements in the building of the Greek identity.

"Este trabajo se ha realizado en el marco del Proyecto HAR2009-07448 del Ministerio de Ciencia e Innovación.
PALABRAS CLAVES: Iconografía griega, comercio griego, etnicidad, Iberia, Mar Negro, mujer, ser híbrido.

KEY WORDS: Greek iconography, Greek trade, ethnicity, Iberia, Black Sea, woman, hybrid being.

El siglo IV a.C. es el momento de esplendor del comercio griego en Iberia. Miles de vasos áticos llegan a la Península y con ellos sus imágenes, exóticas y fascinantes para la mirada ibérica. Sus formas y contenidos son reapropiados por los nuevos consumidores e integrados en sus propias estructuras sociales, políticas e ideológicas. La dinámica comercial y la inmersión en el universo ibérico de estos artículos de lujo, en los que la imagen es privilegio de unos pocos, quizás estimuló demandas específicas, tanto del tipo de vaso como de determinadas representaciones. Nos centraremos aquí en dos de ellas, la de las Amazonomaquias y las de Grifomaquia y analizaremos paralelamente su distribución y posible significado en otras zonas de la oikoumene griega. Ambos temas, que los talleres cerámicos atenienses destinan a las áreas periféricas, gozan en el siglo IV a.C. de una popularidad enorme. ¿Sirven ambos para pensar la frontera? ¿Cómo se dibuja esa linde que separa la oikumene de la eschatiá? ¿A qué obedece la elección de estos temas y cual es su clientela? ¿Se configura un concepto espacial a través de las imágenes, válido tanto para las zonas del Mar Negro como para las lejanas tierras de occidente en el ámbito ibérico? Estas son algunas de las preguntas a las que trataremos de hallar respuesta. 


\section{LAS AMAZONAS}

Desde el inicio, las Amazonas aparecen ligadas a los márgenes o al menos a los límites, en el sentido amplio del término. Cronológicos, puesto que las primeras menciones que aparecen en Homero las sitúan antes de la Guerra de Troya ${ }^{1}$. Geográficos, al ubicar su reino más allá de los territorios conocidos. Situadas en un primer momento en Anatolia ${ }^{2}$, a medida que los griegos van ampliando su conocimiento del mundo, el reino de las Amazonas se aleja, situándose en tierras cada vez más remotas: en el Mar Negro (Herodoto 9, 27 A), al norte del río Tanais y del Lago Maiotis (Eurípides, Herc. 408-410; Propercio, 3,11, 13-14; Estacio, Silv. I, 6, 53-66; Claudiano, rapt. Pros. 2, 62-66), en algún lugar entre el Mar Negro y el Mar Caspio (Estrabón 11, 5, 1-2, Diodoro de Sicilia 17,77), o incluso en Libia (Diodoro de Sicilia $3,53,4)$.

A estos límites cronológicos y geográficos hay que añadir probablemente el más interesante en la medida en que explica la importancia de estas mujeres en el imaginario griego: el conceptual. En efecto, las Amazonas constituyen la imagen de la alteridad por excelencia. Son, por así decirlo, el antigriego perfecto. Nos hallamos, como suele ser frecuente en el mundo griego, ante un mito de inversión, que gira en este caso en torno al mundo femenino y que traduce en el fondo un temor ante comportamientos diferentes a los normalizados, en este caso, probablemente el más complejo y articulado (Toso 2002; Fornasier 2007). Si retomamos el famoso adagio recogido por Diógenes Laercio y atribuido a Tales de Mileto: "doy gracias a los dioses por ser hombre y no animal, por ser varón y no mujer, por ser griego y no bárbaro" las Amazonas encarnan "lo otro" por antonomasia: son mujeres, bárbaras y animales en la medida en que no han pasado por el yugo de la domesticación masculina: el matrimonio.

Antítesis por excelencia del varón griego que las concibe y articula son sus más extraordinarias adversarias y, por lo tanto, construidas a su medida. No en vano serán sistemáticamente derrotadas por sus más gloriosos héroes, Heracles (Eurípides, Herc. 408-418; Ion, 1144-1145), Aquiles (Arktinos, Aithiopis, resumida por Proclo, 51-56 ed. Kullmann; Apolodoro, Epitome 5,1) o Teseo (Diodoro 4, 16, 4; Plutarco,

${ }^{1}$ Así se menciona en la Ilíada la tumba de Myrina, una de sus reinas (II, 810), Príamo las habría encontrado en su juventud en Frigia (III, 184) y el héroe Belerofón se habría enfrentado a ellas (VI, 186).

${ }^{2}$ A orillas del río Thermodon, (el actual Terme Çay al noreste de Turquía), siendo su capital Temiscira. Cf., Esquilo, Prom. 721-725; Justino, 2,4,2).
Thes. 26-27. Por otra parte, lejos de ser figuras monolíticas, la propia existencia de las Amazonas se articula en la medida en que obedecen a la época que las reclama en sus mitos y leyendas y en este sentido y en palabras de Lissarrague y Schmitt-Pantel aparecen como "l'expression d'un imaginaire à la fois toujours semblable et toujours différent" (Lissarrague y Schmitt-Pantel 2008: 43).

Pero detengámonos en las nociones que han retenido los pintores de vasos de estas temibles y fascinantes guerreras.

La representación de las Amazonas constituye uno de los temas más representados en época arcaica y clásica hasta el punto de que ya en 1957, Bothmer recogía más de 1000 vasos para estos periodos en la que será la primera recopilación exhaustiva del tema ${ }^{3}$. Si exceptuamos alguna representación aislada, las Amazonas irrumpen con fuerza en la pintura de vasos ática, de figuras negras, a partir del 600 a.C. De los tres ciclos mayores en los que se articula la representación de las Amazonas y que giran en torno a los grandes héroes que mencionábamos antes, las primeras imágenes aparecen focalizadas en aquel que conocerá un mayor éxito: el enfrentamiento con Heracles, que se inscribe dentro del noveno de los erga encargados por Euristeo: el robo del cinturón de Hipólita (Giuman 2002), reina de las Amazonas, para lo que Heracles parte en expedición a las lejanas tierras del Cáucaso, episodio que gozará de una gran popularidad hasta el punto de ser el más representado por los pintores tras el del león de Nemea. En estas primeras imágenes (Devambez 1981: 589 n² 26), las Amazonas aparecen como hoplitas y solo la convención de pintar las partes desnudas de la mujer en color blanco permite diferenciarlas de sus oponentes griegos, con los que comparten la apariencia a todos los niveles, excepción hecha del desnudo heroico reservado exclusivamente al varón. La victoria del héroe se codifica a través del gesto de agarrarla por el casco, como observamos en numerosos ejemplos (Devambez 1981: 589 n 23). (Fig. 1).

Al tratarse de mujeres guerreras, el robo del cinturón solo puede resolverse mediante la lucha y la consiguiente derrota de las Amazonas. Algunos gestos precisos nos dejan entrever ya la lectura profunda que los griegos hacían de este enfrentamiento legendario. En efecto, el robo del cinturón ha de ser leído en clave de posesión erótica en la medida en que el

\footnotetext{
${ }^{3}$ Los estudios de Bothmer junto al de Devambez en 1981 siguen siendo los más completos sobre la iconografía de las Amazonas si bien este tema iconográfico y las diversas lecturas que se desprenden a lo largo de distintas épocas han conocido una vasta literatura en los últimos años: Giuman 2002 y 2006; Leduc 2008.
} 


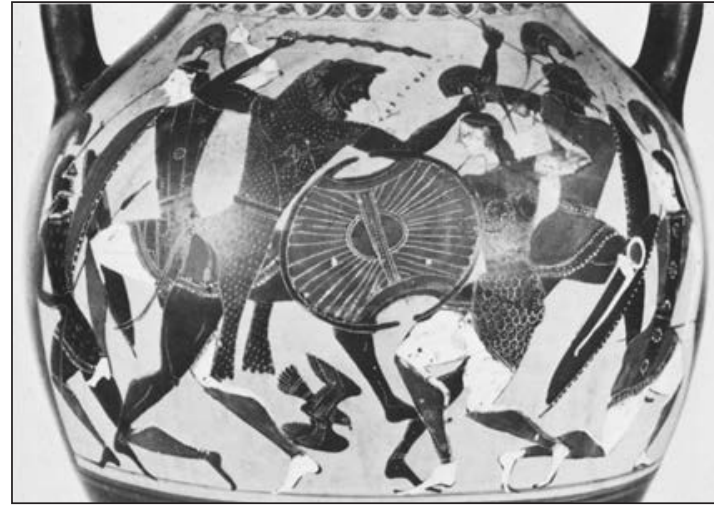

Figura 1. Ánfora ática del Pintor de Berlín 1686 (posterior a 550 a.C.). Bolonia, Mus. Civ. PU 192. Fotografía: Devambez 1981, pl. $444, n^{\circ} 23$.

gesto de desatar el cinto está estrechamente ligado a los rituales en torno al acto sexual.

Hacia mediados del siglo vi a.C. las Amazonas comienzan a ser representadas a la oriental (Devambez 1981: 631 n $^{\circ}$ 729) (Fig. 2), es decir, vestidas con pantalones, gorro frigio y las armas propias de los escitas como el hacha, el arco, el gorytos o la pelta. Cabría pensar que el cambio en su atuendo, de hoplita a oriental, podría deberse a la influencia de los contactos griegos con el mundo persa o con las lejanas tierras del Ponto. Nada más lejos de la realidad.

Las Amazonas seguirán siendo figuradas bajo los dos esquemas y, en innumerables ocasiones, dentro del mismo vaso como en el ejemplo mencionado. Es más, las Amazonas hoplitas podrán utilizar las armas propias de las Amazonas orientales (Devambez 1981:

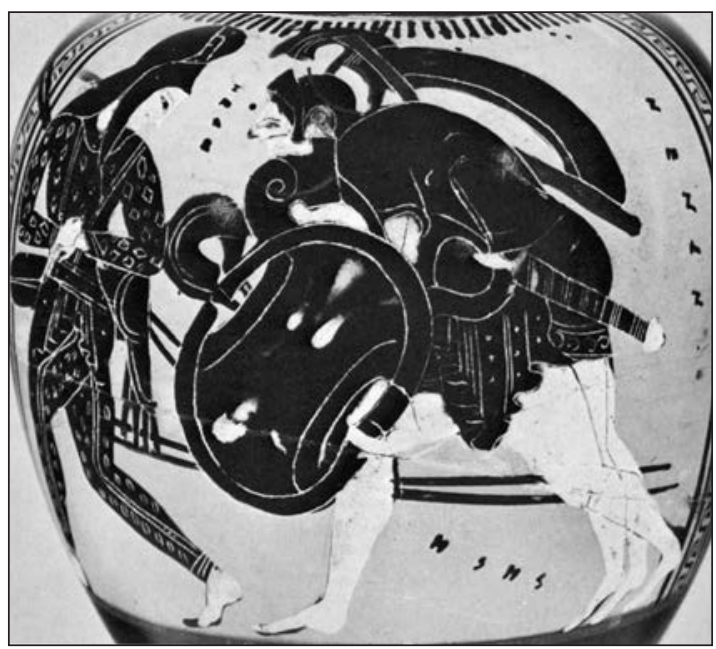

Figura 2. Enócoe ática (hacia 500 a.C.). Würzburg, Martin von Wagner-Mus. 347. Fotografía: Devambez 1981, pl. 518, nº 729.
$591 \mathrm{n}^{\circ}$ 62). No será hasta bien entrado el siglo v a.C. cuando los pintores se decanten de manera más resuelta por el esquema oriental.

La versatilidad en la representación de las Amazonas nos permite afirmar que hay un juego entre lejanía y proximidad dentro del mito que subyace en la representación. Al figurarlas como hoplitas, los pintores griegos inciden por así decirlo en ese adversario perfecto que es su igual al otro lado del espejo; al figurarlas como orientales sitúan el marco de la acción en tierras lejanas introduciendo además la distancia conceptual que les separaba de este tipo de antimujer. Uno de los ejemplos más locuaces lo hallamos en el medallón de una copa ática de figuras rojas del Pintor Douris, fechada hacia el 490-480 a.C. y hallada en Chiusi (Devambez 1981: 633, no 759) donde se superponen dos amazonas en cada uno de los esquemas. Probablemente nos hallemos ante uno de los pocos casos en la iconografía griega en que un personaje es representado bajo un distinto esquema iconográfico dentro de un mismo vaso. (Fig.3).

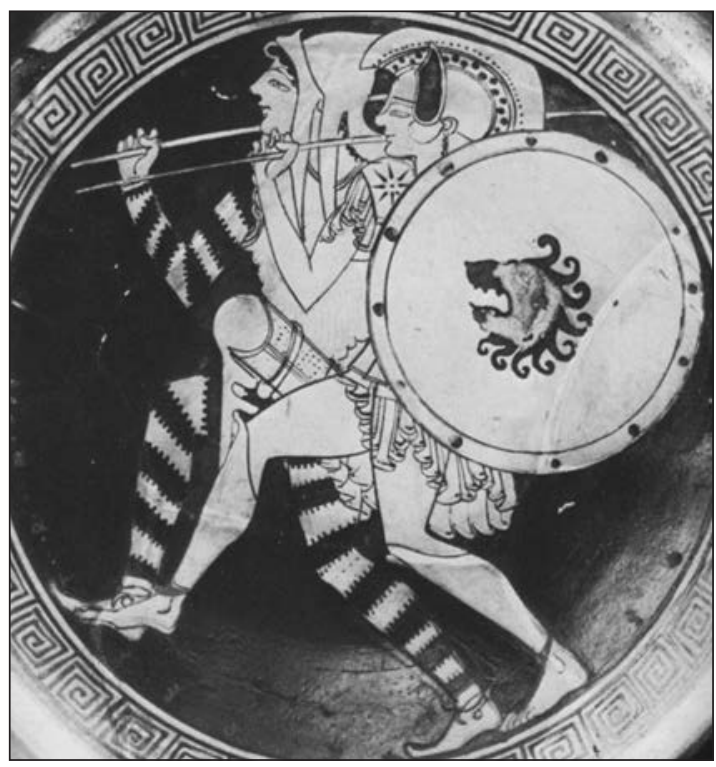

Figura 3. Copa ática atribuida a Douris (490-480 a.C.). Baltimore, Johns Hopkins Univ. Fotografía: Devambez 1981, pl. 520, $n^{\circ} 759$.

Las Amazonomaquias irán incorporando paulatinamente nuevos elementos. Así, desde el último tercio del siglo VI a.C. aparecen ya montadas a caballo (Devambez 1981: 624, n 579; 631 n $^{\circ} 721$ ). Se introduce también el carro (Devambez 1981: 632 n 753) e incluso las vemos aparecer en momentos previos al enfrentamiento, paralelos a los de los hoplitas griegos, como el revestir las armas (Devambez 1981: $632 \mathrm{n}^{\circ}$ 
743) Surgen también imágenes de Amazonas a caballo y rodeadas de sus perros (Madrid, MAN 10921) (Fig. 4) cercanas a las escenas de caza propias también del mundo aristocrático masculino. Esta relativa tardía incorporación del caballo en el mundo de las Amazonas, cuando las fuentes literarias insisten en su excelencia como jinetes y en su estrecha vinculación con los caballos, quizá sea ahora el reflejo de un conocimiento más real de las costumbres escitas y de los pueblos del Ponto en los que se inspiraba la construcción de sus adversarias.

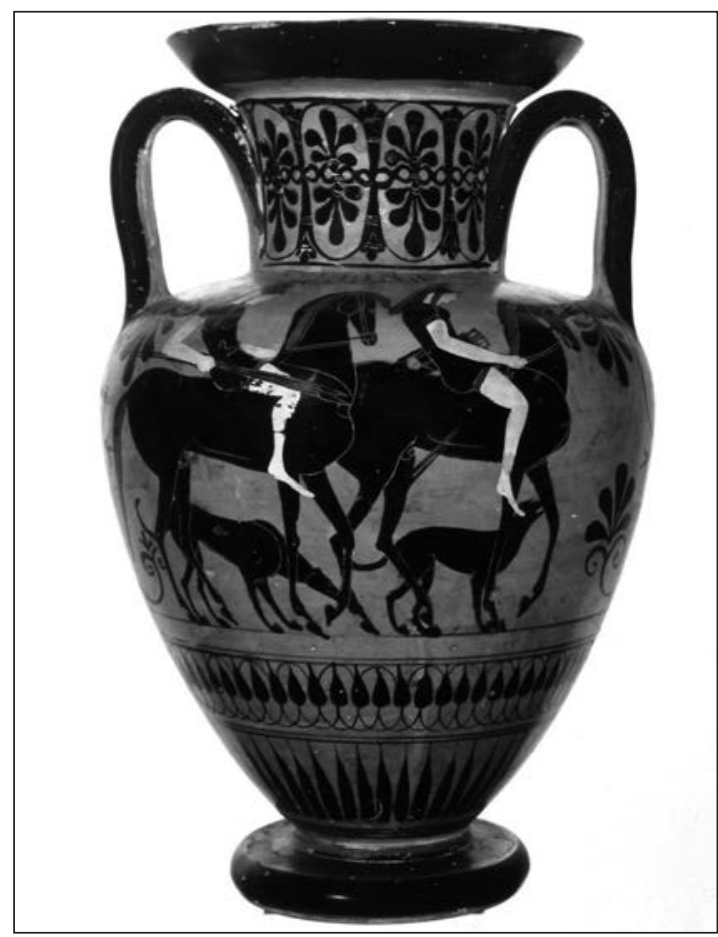

Figura 4. Ánfora ática (520-500 a.C.) Madrid, MAN, nº inv. 10921. Fotografía: Museo Arqueológico Nacional.

Las Amazonomaquias conocerán un interés renovado en el último tercio del siglo vi y principios del $\mathrm{V}$ a.C. Ahora, la figura de Heracles se hace menos presente a favor de la irrupción de Teseo el héroe educado en la palestra y garante del orden cívico, lectura en la que también tienen cabida las Amazonas, antítesis perfecta de los valores de la polis (Madrid, MAN 11013) (Fig. 5). Más allá de esta lectura de fondo, la incursión de las Amazonas en el Ática y su derrota por $\mathrm{Teseo}^{4}$ debe inspirarse en las invasiones

\footnotetext{
${ }^{4}$ Según la posible Teseida perdida y recogida por Plutarco (Thes. 28) Teseo habría raptado a Antíope reina de las Amazonas y la habría conducido hasta Atenas. Las Amazonas
}

persas (490 a.C. o la de 478/9 a.C.) y funcionar como modelo mítico, como prefiguración de la derrota real de los Persas por Atenas. Asistimos ahora (Devambez 1981: $602 \mathrm{n}^{\circ} 233$ y 240) a escenas de combate con multitud de oponentes que probablemente hallen inspiración en las pinturas murales de Mikon del Theséion y de la Stoa Poikile (460-438 a.C.). En muchas de estas abigarradas composiciones no interesa tanto el episodio mítico en su origen como el mostrar la batalla perfecta entre griegos y Amazonas (Devambez $606 n^{\circ} 302$ ).

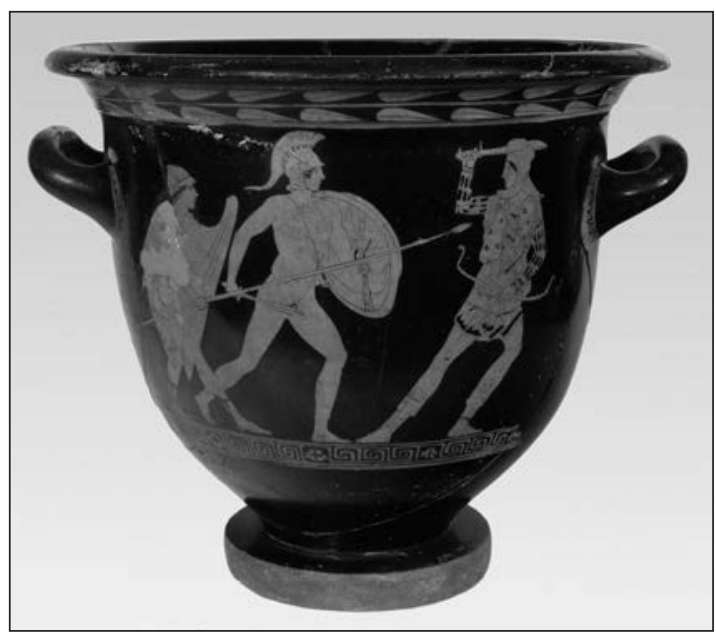

Figura 5. Cratera de campana ática del Pintor de Polignoto (430-420 a.C.). Madrid, MAN, no inv. 11013. Fotografía: Museo Arqueológico Nacional.

El comienzo del siglo v a.C. marcará un punto de inflexión en la representación ligado a los acontecimientos históricos que sacuden Atenas y así, por primera vez, las Amazonomaquias no solo aparecen en la cerámica sino que inundan las representaciones escultóricas de la época. Las vemos entre las metopas del Tesoro de los Atenienses de Delfos (erigido en torno al 490 a.C.), en el escudo de la Atenea Parthenos (447-438 a.C.) o en las metopas del lado oeste del Partenón (447-440 a.C.), por no citar más que algunos ejemplos ${ }^{5}$.

habrían partido en expedición al rescate de su reina llegando hasta las mismas puertas de la polis. Según Esquilo aún, las Amazonas habrían acampado en el Areópago. Cf. Boardman 1982.

${ }^{5}$ Podríamos añadir aún el frontón oeste del templo de Ares, en el Ágora de Atenas o las metopas del Templo de Hera en Argos (último cuarto del siglo v a.C.), el friso del heroon de Gjölbaschi-Trysa de inicios del siglo IV a.C., o el frontón del templo de Asclepios, obra de Timotheos, en Epidauro (395375 a.C.). 
Tras el saqueo de Atenas en el 480 a.C. y la victoria definitiva en Platea en el 479 a.C. la oposición ética entre el modelo helénico y el bárbaro se convierte en el verdadero eje de todo el discurso ideológico de Atenas en cualquiera de sus expresiones, ya sean estas escritas o visuales (Castriota 2000: 443-479). Las representaciones de las Amazonomaquias seguirán produciéndose a lo largo del siglo $\mathrm{v}$ a.C. pero, por lo general, pierden parte de su fuerza (Devambez 1981: $607 \mathrm{n}^{\circ} 324$ y $608 \mathrm{n}^{\circ} 328$ ).

¿Qué sucede en el siglo Iv a.C.?, ¿Siguen siendo aún útiles para pensar "lo otro", lo lejano y exótico?, ¿siguen siendo vehículo para expresar los cauces de la domesticación femenina?, ¿funcionan aún como imagen mental de la parthenos contrapuesta al mundo reglado del gineceo? (Badinou 2003). Lejos de desaparecer, las Amazonas parecen cobrar una nueva vida y una vez más nos deparan algunas sorpresas.

Aunque las representaciones de Amazonomaquias siguen al uso, resulta ahora prácticamente imposible saber si la escena se inscribe dentro de alguno de los tres grandes ciclos (Heracles, Aquiles o Teseo), algo que por otra parte ya venía sucediendo en el último cuarto del siglo v a.C. (Devambez 1981: 608 n $^{\circ} 329$ ). Asistimos más bien a escenas de batalla genéricas en las que el número de oponentes se ve también reducido. Detengámonos ahora en el soporte de la imagen y el área de recepción de los vasos.

En primer lugar, observamos que mientras que la imagen de las Amazonas aparecía en épocas anteriores de forma relativamente esporádica en las áreas periféricas del Mediterráneo (Península Ibérica, región del Ponto $^{6}$ o norte de África) cobrarán ahora una presencia inusitada en particular en el área del Mar Negro y en alguna menor medida en el Adriático norte y la región cirenaica ${ }^{7}$. Por otra parte, si hasta ahora hemos visto que la representación de las Amazonas podía hallarse prácticamente en cualquier soporte cerámico, desde las crateras a los lécitos, pasando incluso por los epinetra (Badinou 2003), ahora aparecen fundamentalmente en pélices en el Mar Negro y Cirenaica, sobre todo en las conocidas como "pélices de Kerch". Las veremos también en menor número en lecánides, lécitos y en alguna cratera, como en Koshary, al oeste de Olbia (Papuci-Wladyka et alii. 2008: 40) (Fig. 6) que, sin embargo, es la forma más frecuente en la Península Ibérica.

\footnotetext{
${ }^{6}$ Beazley Archive 24841. Moscú, Puskhin State MFA F 1005. Copa ática de figuras rojas atribuida al Grupo de Polygnotos, hallada en Phanagoria (Rusia) y fechada entre 450-400 a.C.

${ }^{7}$ La representación de las Amazonas conoce un particular interés aún entre los primeros pintores de la región de Apulia donde se cuentan dieciocho vasos con escenas de Amazonomaquia entre el 430 y el 390 a.C. Cf. Roscino 2011: 207.
}

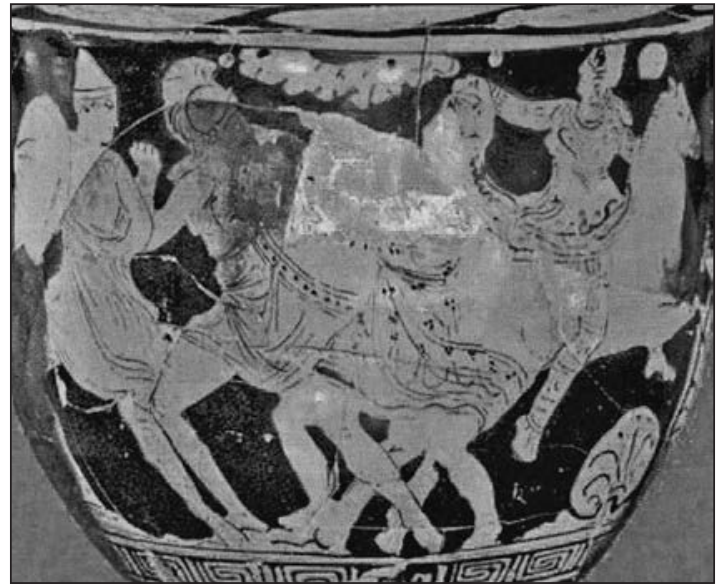

Figura 6. Cratera de campana ática hallada en Koshary, Ucrania (Ca. 350 a.C.). Fotografía: Papuci-Wladyka 2008: 40.

\section{LA GRIFOMAQUIA}

El mítico combate entre grifos y Arimaspos eclosionó con fuerza sorprendente en las imágenes vasculares áticas a fines del siglo $\mathrm{v}$ y se popularizó a lo largo del IV a.C. (Gorbounova 1997: 529-534). Este combate fabuloso entre aquellas criaturas híbridas, guardianes del oro que arrancaban de las entrañas de la tierra, y los no menos fantásticos guerreros de un solo ojo, que intentaban arrebatarles sus riquezas, fue plasmado por primera vez en imágenes a fines del siglo vi a.C., sobre una hidria de Caere (Gorbounova 1997: 529, no 1), la única representación realmente narrativa que incluye el robo del oro. Sin embargo, su aparición fue efímera, pues, no volverá a ser representado hasta un siglo después.

La leyenda de los Arimaspos y de su combate contra los grifos es muy anterior a su popularización en la iconografía cerámica ática ${ }^{8}$. Recogida por primera vez por Aristeas de Proconeso a fines del viI a.C. (Bernabé 1979: 344-354) debió tener una limitada difusión, pues solo se encuentran trazas de ella en unos pocos autores del siglo v a.C. ${ }^{9}$.

${ }^{8}$ Herodoto (III, 115-116; IV, 13-15 y 27) los menciona en su Libro III cuando habla de los confines del mundo y describe las riquezas fabulosas de estas regiones. Vuelve más ampliamente sobre esta leyenda en el Libro IV cuando cita como fuente la lectura del poema de Aristeas de Proconeso, la Arimaspea. También cita como fuente una encuesta realizada por él mismo entre los escitas, ellos mismos deudores en sus conocimientos sobre los Arimaspos de los misteriosos Isedones, pueblo del interior del Mar Negro ya conocido por Hecateo de Mileto (Herodoto, IV, 14). Por ellos había aprendido el origen del nombre de los Arimaspos, que significaba en la lengua escita "aquellos que poseen un solo ojo" (Herodoto, IV, 27).

${ }^{9}$ Píndaro lo conocía (frag. 271) y el logógrafo Damasteo de Sigea (ap. Esteban de Bizancio, s.v. "Hyperboroi" =FGrHist 
A través de Herodoto y de otras fuentes sabemos que los Arimaspos son descritos como personajes extraordinarios: solo tienen un ojo, se desplazan a caballo, mantienen una guerra perpetua contra los grifos, que defienden el oro que extraen de cavernas subterráneas, y viven en los confines del mundo, al norte de los Isedones, otro pueblo septentrional cuyos confines permanecen igualmente vagos, y al sur de la región que pertenece a los grifos. Al norte de estos últimos se extendía el país de los Hiperbóreos, que tenía por límite septentrional el Océano que rodeaba el mundo habitado.

El emplazamiento de este pueblo fabuloso puede diferir de unos autores a otros. El paisaje brumoso del norte, hacia el interior del Mar Negro, domina en la mayoría de los relatos sobre los Arimaspos. Pero otros autores los colocan entre los pueblos orientales ${ }^{10}$. En todos los casos, los Arimaspos pueblan el espacio de los confines, inestable y mal conocido.

La eclosión de las imágenes áticas de la Grifomaquia en el siglo IV a.C. no se corresponde, por tanto, a la existencia de una arraigada tradición literaria o iconográfica. Si las representaciones de grifos, aislados o en combate con otros animales, habían sido y eran habituales en la pintura de vasos de toda la geografía griega desde el siglo viII a.C., o incluso anteriores, de época micénica, su combate contra los Arimaspos fue una innovación de los pintores atenienses del siglo v a.C. (MacDonald 1987). Había sido habitual el relato en palabras e imágenes del enfrentamiento de hombres contra híbridos, del héroe contra el monstruo, siempre en combate singular, pero nunca se particularizó esta lucha mítica ni en la figura del grifo ni de una colectividad, de un pueblo y, para más señas, tan mítico y fabuloso como los Arimaspos. ¿A qué se debe ese súbito interés por una leyenda que no tenía arraigo en la tradición literaria o iconográfica?

Decíamos que no es hasta fines del v, y sobre todo a lo largo del Iv a.C., cuando el tema conoció un cierto éxito. En Atenas esta popularidad es coherente con la predilección por las escenas de combates, históricos

I A, F 1, 153-154) nombraba a los Arimaspos en una de sus obras, añadiendo que los montes Rhipeos formaban el límite septentrional de su territorio. Esquilo, cuya fuente probable es el poema de Aristeas, menciona a los Arimaspos en el Prometeo encadenado (vv. 803-807) entre los pueblos orientales visitados por Ío en su viaje. El retrato conciso de Esquilo retoma las singularidades físicas que ya habían sorprendido a Herodoto, pero es el primero que presenta a los Arimaspos como temibles jinetes, implicados en una lucha sin fin contra los grifos para poseer el oro del río Plutón. Calímaco, Estrabón, Luciano, Plinio, Pomponio Mela y otros autores posteriores al momento que nos ocupa (Gorbounova 1997: 529) también recogen noticias sobre los Arimaspos.

${ }^{10}$ Así, Amiano Marcelino (XXIII, 13) los sitúa en Persia y Eliano (De natura animalium, IV, 27) en la India.

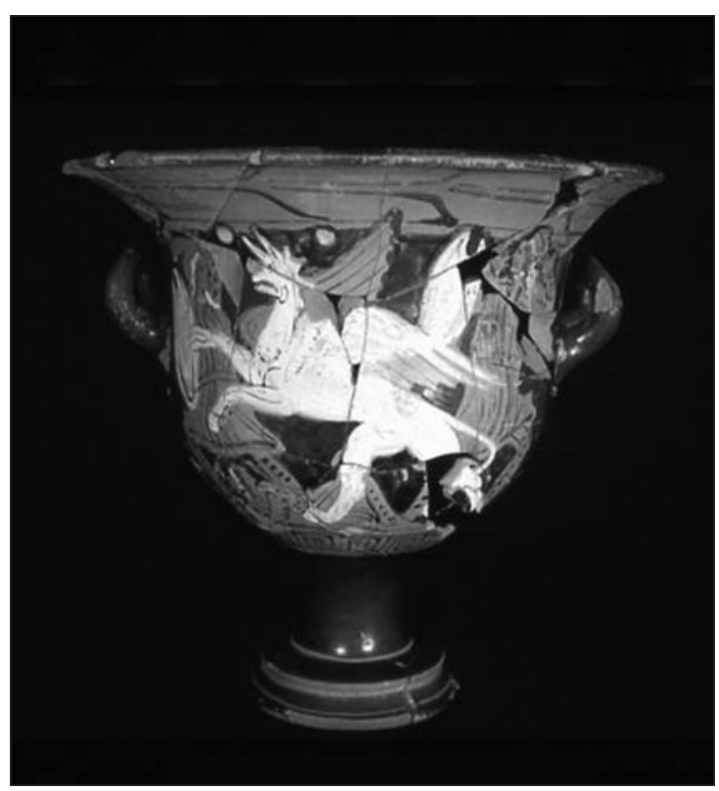

Figura 7. Cratera de campana ática del Pintor de la Amazona (400-350 a.C.), procedente de L'Orleyl. Fotografía: Lázaro et alii 1981, lám. X.

o míticos, que se afirma en el $\mathrm{V}$ y se refuerza en el IV. Las escenas de Grifomaquia (MacDonald 1987: 23-45) representan a los Arimaspos sin hacer alusión a su anomalía física — un solo ojo — y les visten a la manera oriental, con pantalones, camisas de manga larga y ependytes, gorro frigio y botas. Combaten con lanzas o espadas y se protegen con escudos de tipo oriental, la pelta. A veces luchan contra los grifos a pie (Fig. 7), otras montados a caballo (Fig. 8), otras sobre carros (Fig. 9). En ocasiones la escena se sintetiza en un combate singular entre un único grifo y un solo Arimaspo (Madrid, MAN 11210) (Fig. 10), aunque ello se debe a condicionamientos del espacio pictórico, pues esta reducción del esquema se aplica en las pélices y no en las crateras. La simplificación del motivo y de la escena puede llegar a ser radical, si interpretamos la imagen del prótomo de grifo o de la cabeza de un Arimaspo, frecuentes por ejemplo en el medallón interior de las copas del Grupo de Viena 116 (Beazley 1963: 1526-1528), como una síntesis de un trasfondo narrativo, la Grifomaquia, ya conocido por el pintor y el consumidor de los vasos y sus imágenes.

A veces, las Grifomaquias se combinan en la otra cara del vaso con Amazonomaquias ${ }^{11}$, e incluso, observamos Grifomaquias donde las Amazonas

${ }^{11}$ Beazley Archive 230453. Odessa, Museum of Western and Eastern Art 22051. Pélice ática de figuras rojas, atribuida al P. de la Amazona y hallada en el sur de Rusia, 400-300 a.C. 


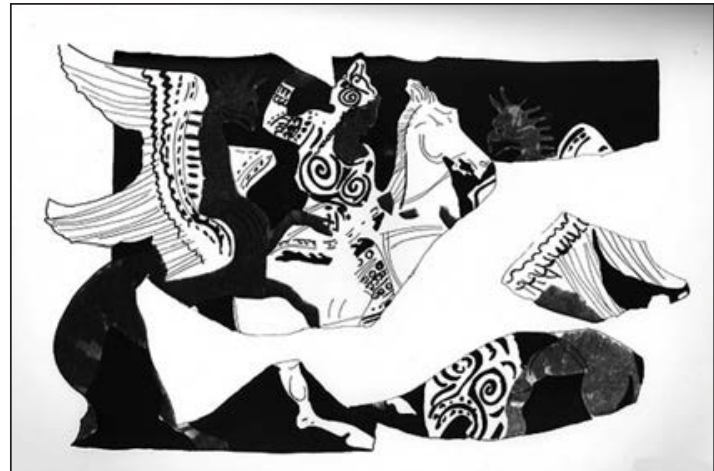

Figura 8. Cratera de campana ática procedente de Toya. (400350 a.C.) Madrid, MAN, nº inv. 1986/149/477. Dibujo: Sánchez $1992, n^{\circ} 477$

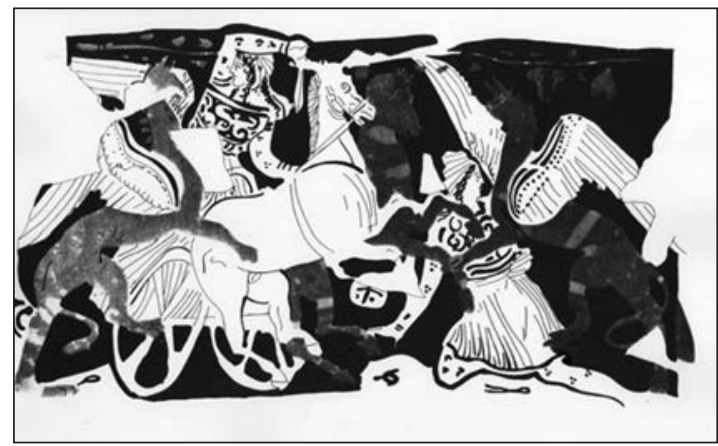

Figura 9. Cratera de campana ática próxima al Pintor de la Grifomaquia de Oxford, procedente de Castellones de Ceal. (375350 a.C.). Dibujo: Sánchez 1992, no 267.

reemplazan a los Arimaspos ${ }^{12}$ en lo que, en una primera lectura, aparece como una contaminación de ambos temas. Debido a la caracterización oriental de los Arimaspos, a veces es difícil distinguirlos de las Amazonas o de otros guerreros orientales (D'Ercole 2009: 214). Cuando encontramos cabezas orientales representadas con carnaciones en pintura blanca y/o con pendientes, se trata claramente de una Amazona; en caso contrario, resulta imposible precisar su personalidad mitológica. En esta fusión iconográfica encontramos representaciones que asocian la cabeza de la Amazona, con el prótomo de un grifo (Catálogo Nymphea p. $55 \mathrm{n}^{\circ}$ 23) (Fig. 11) y/o el de un caballo (Beazley Archive 230479), (Fig. 12), el más frecuente con diferencia, aunque en ocasiones puede aparecer una cabeza de Arimaspo entre dos cabezas de grifo

${ }^{12}$ Beazley Archive 230456. Yalta, Museum KM 504, pélice ática de figures rojas atribuida al P. de la Amazona, hallada en el sur de Rusia, 400-300 a.C.

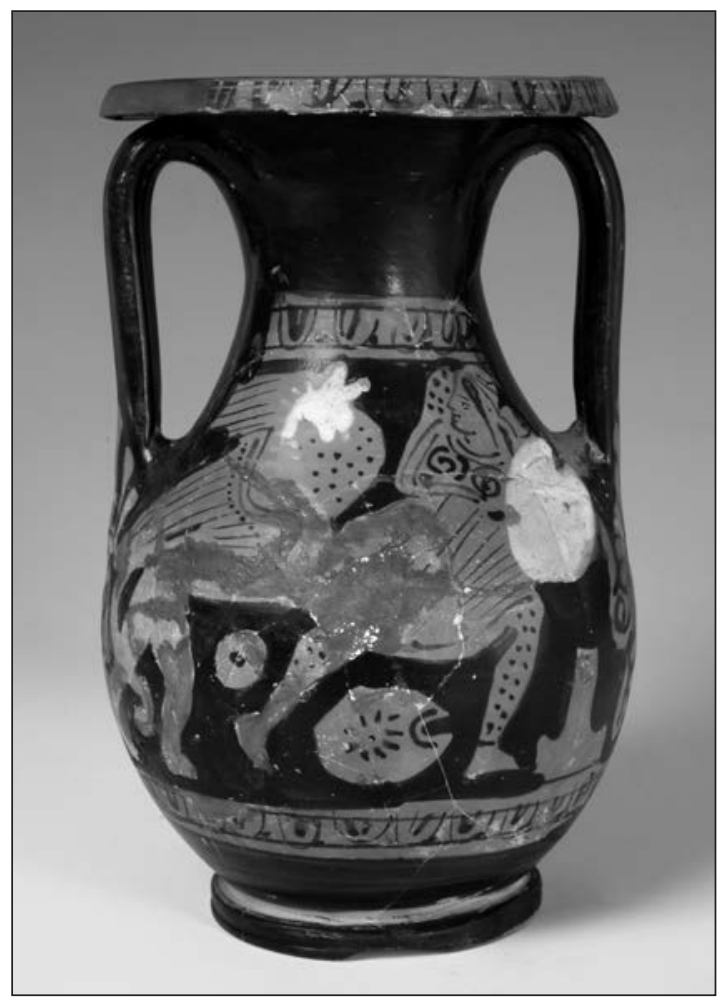

Figura 10. Pélice ática del estilo de Kertch (350-325 a.C.). Madrid, MAN, no inv. 11210. Fotografía: Museo Arqueológico Nacional.

(Fig. 13) e incluso, dos prótomos de grifo afrontados ${ }^{13}$. Este tipo de esquema compositivo, particularmente apreciado en el Mar Negro, parece nacer en los Talleres del Grupo G y en los del Pintor de la Amazona con gran difusión en el área del Bósforo, Adriático, Iberia y Cirenaica. Si bien es cierto que ya existían representaciones de cabezas aisladas de Amazonas ${ }^{14}$, la asociación con el grifo es completamente novedosa pues conviene recordar que ningún mito o leyenda conocido los asocia. Por otro lado, hemos pasado de las Amazonas innumerables, por así decirlo y, en ocasiones individualizadas como nos lo mostraban sus nombres inscritos en los vasos, y de los numerosos Arimaspos, a figuras aisladas, con la consiguiente carga semántica, que quizá deba ser leída como una especie de colectivo, de icono de un pueblo.

${ }^{13}$ Beazley Archive 9008376. Moscú, Puskhin State MFA F 1332, pélice fragmentaria ática de figuras rojas, hallada en Phanagoria (Rusia), 400-300 a.C.

${ }^{14}$ Beazley Archive 276066. Basilea, Antikenmus. BS 461, Lécito ático de figuras rojas atribuido al P. de Aquiles, 475425 a.C. 


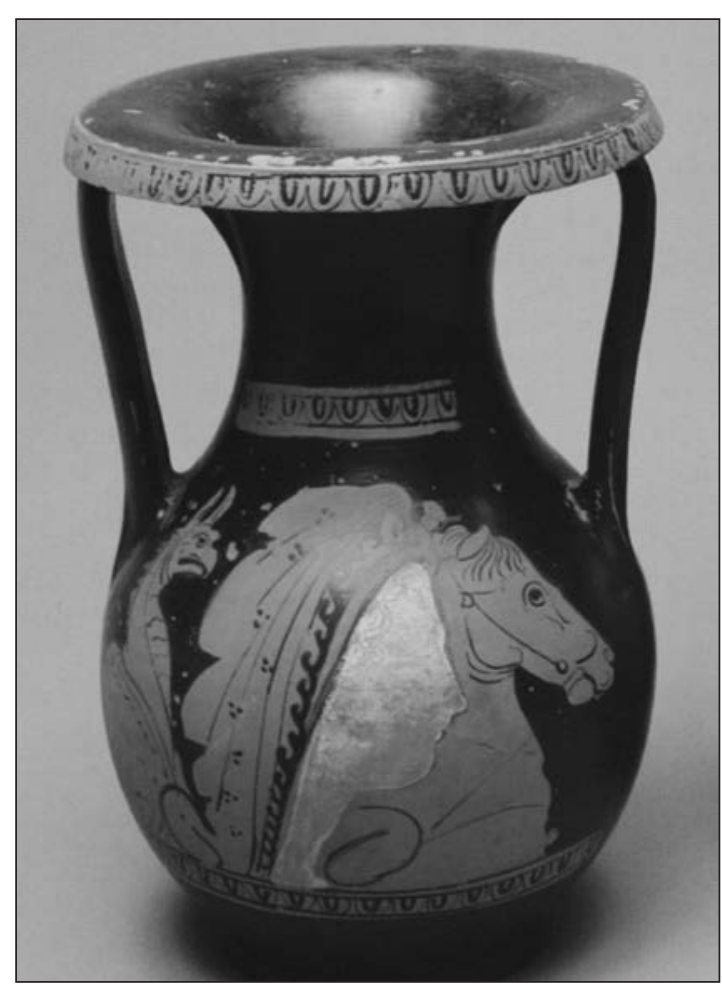

Figura 11. Pélice ática del Grupo G del Maestro de Pélices (350325 a.C.). San Petersburgo, Hermitage GK/H15. Fotografía: Catálogo Nymphea p. $55 \mathrm{n}^{\circ} 23$.

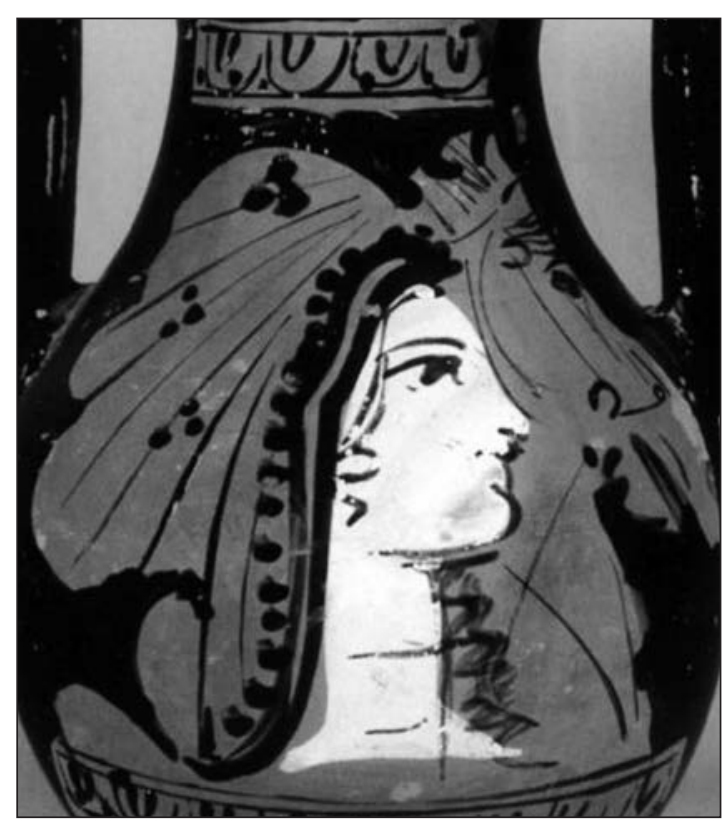

Figura 12. Pélice ática del Pintor de la Amazona (400-300 a.C.). Atenas, Mus. Nat. E 674. Fotografía: Beazley Archive 230479.

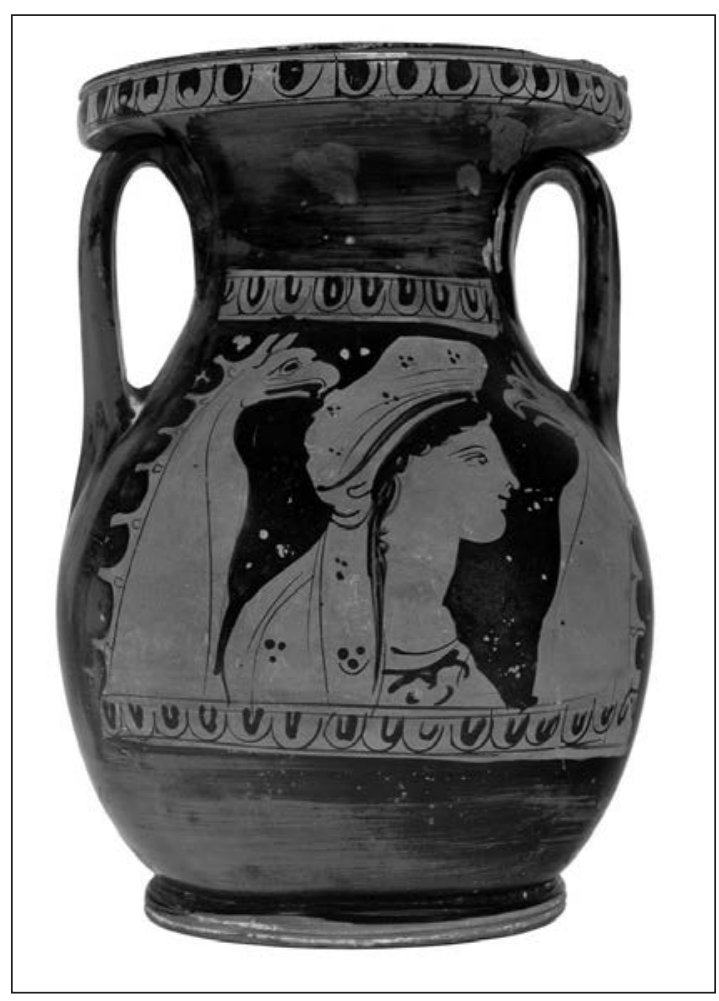

Figura 13. Cratera ática procedente de Galera (400-350 a.C.). Madrid, MAN, nº inv. 1979/70/GAL/T77/1. Fotografía: Museo Arqueológico Nacional.

\section{TALLERES, PINTORES Y COMERCIO}

Entre los talleres y pintores recogidos por Beazley (Beazley 1963: 1407-1528) ${ }^{15}$ que escogen ambos temas para decorar sus producciones destaca el llamado Grupo G, que produce mayoritariamente pélices. Le siguen el Grupo del Fat Boy, el Pintor de la Amazona $^{16}$, el Pintor de la Lecánide de Viena, el Pintor de Filottrano ${ }^{17}$, el Pintor de Ferrara T 408, el Pintor de la Grifomaquia de Oxford, el Pintor del Bizco, el Pintor London Griffin-Calyx, el Pintor de Londres F6, el Pintor de Munich 2365, el Grupo de York-Reverse, (Fig. 14), el Grupo de Viena 116 y, finalmente, otros no identificados cuyos vasos, especialmente pélices, se han incluido en el llamado estilo de $\mathrm{Kerch}^{18}$.

\footnotetext{
${ }^{15}$ Los datos están también extraídos de consultas en la base de datos del Beazley Archive (http://www.beazley.ox.ac.uk/ $\mathrm{xdb} / \mathrm{ASP} /$ default.asp)

${ }^{16}$ Beazley Archive 230443. Amsterdam, Allard Pierson Museum 957. Pélice ática hallada en Kerch, 400-300 a.C.

17 Además de los vasos recogidos por Beazley, hemos añadido los publicados por M. Landolfi 2000: 77-91.

${ }^{18}$ Beazley Archive 1011816. Cracovia, Arch. Mus. 3591. Pélice ática de figuras rojas con escena de Grifomaquia hallada en Kerch, 400-300 a.C.
} 


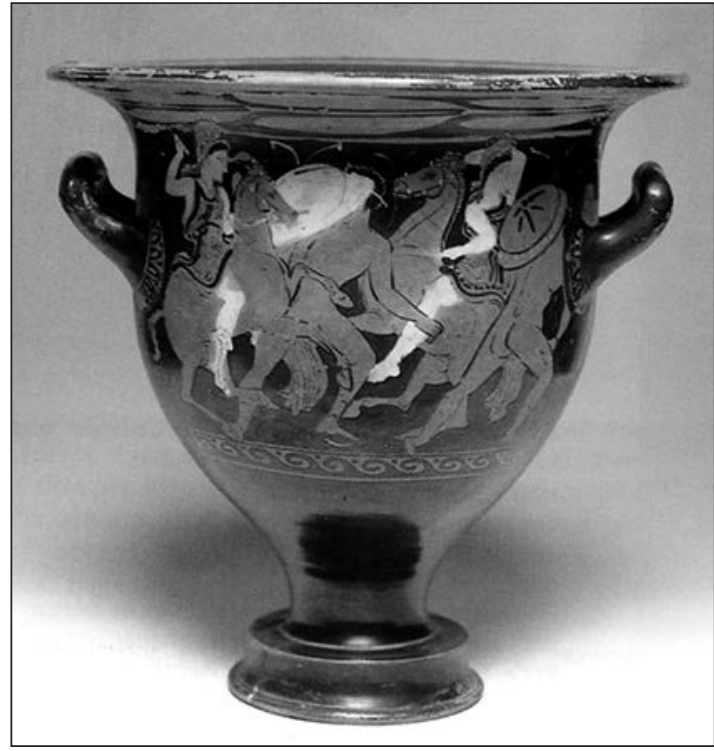

Figura 14. Cratera ática del York-Reverse Group, procedente de Baza. (400-375 a.C.). Madrid, MAN, no inv. 1969/68/29. Fotografía: Museo Arqueológico Nacional.

En conjunto, los vasos decorados con estas escenas muestran una alta especialización de los talleres áticos, que se manifiesta a la vez en la elección de los temas figurados y de las áreas de destino de sus productos. En efecto, cuando se conoce su procedencia, cuatro regiones destacan sobre las demás: el Mar Negro -incluyendo aquí las regiones más próximas como la Calcídica- (Bouzek 1989; Buravčuk 2010; Hermary 2012), el norte del Adriático (Braccesi y Luni 2004) - especialmente Spina_, Iberia y Cirenaica.

La repartición por talleres de los vasos encontrados en el Ponto Euxino y en Europa oriental demuestra la existencia de las mismas redes que tocaron al Adriático septentrional (D’Ercole 2009: 209-213). La mayoría de los vasos salidos del taller del Grupo G fueron exportados a Spina y a Rusia meridional, a las riberas del Mar Negro, especialmente a Crimea, Kerch y Olbia; una menor parte a Macedonia, especialmente a Olinto, y a la Cirenaica.

Por otra parte, las producciones de los pintores del Grupo de Telos, entre los que se encuentran el Pintor de la Grifomaquia de Oxford, el Pintor del Bizco, el Pintor del Tirso Negro y el Pintor de Toya, están presentes entre las importaciones áticas llegadas a Iberia. Se ha podido constatar que sus vasos están estilística y comercialmente relacionados con los del Grupo G, los del Grupo de Viena 116 y el Grupo del Fat Boy (Sánchez 2000; Cabrera y Rouillard 2004: 91-98). El estilo de dibujo y la temática elegida son muy similares, lo que varía fundamentalmente es el soporte. Pero no es únicamente el análisis estilístico el que permite relacionar todas estas producciones, sino también la comercialización de estos vasos en el Mediterráneo, y su asociación en conjuntos cerrados muy definidos, como el Pecio de El Sec. Los pintores del Grupo de Telos destinan la mayor parte de su producción a ser vendida fuera de Grecia. En la Grecia propia son escasos los vasos hallados y se concentran especialmente en Macedonia. La distribución se realizó preferentemente en el Adriático, Mar Negro y, especialmente, el Mediterráneo Occidental. Los vasos del pintor más prolífico del Grupo, el Pintor del Tirso Negro, aparecen concentrados en el Adriático, sobre todo en Spina, en la costa mediterránea de Francia y, más ampliamente, en la Península Ibérica y, fuera de este ámbito, en Histria, donde sus pélices y crateras se asocian a crateras del Pintor del Bizco, y en Apollonia, en la costa búlgara. También aparecen sus vasos en contextos tracios (Cabrera y Rouillard 2004: 95-96).

La distribución de las copas del Grupo de Viena 116 y de los vasos del Grupo del Fat Boy se concentra igualmente en el Occidente. Incluso las copas del Grupo de Viena 116 no aparecen en el Mar Negro, ni siquiera en los yacimientos donde se documentaban crateras del Pintor del Tirso Negro, y solo una de ellas se documenta en Olinto. En cuanto a los vasos del Fat Boy, la mayoría parecen destinados a Italia y al Mediterráneo occidental. Son especialmente abundantes en Adria, Spina, Enserune, Marsella y en la Península Ibérica, aunque también se documentan en el área del Mar Negro (Cabrera y Rouillard 2004: 95-96).

Parece, pues, que en estas cuatro regiones ${ }^{19}$ (Fig. 15) se concentran con especial intensidad los productos de los mismos pintores y las imágenes de Amazonamaquias y Grifomaquias. Y ello hay que explicarlo, desde luego, por la existencia de una vasta red comercial que llevó los vasos áticos, salidos de los mismos talleres y decorados con los mismos temas, a la vez a Iberia, al Adriático, a Cirenaica y al Mar Negro. Pero, ¿por qué precisamente se envían con preferencia ambas imágenes a estos ámbitos periféricos?

\footnotetext{
${ }^{9}$ Los datos relativos a las áreas de Grecia Norte, Mar Negro, Adriático y Cirenaica con los que se ha confeccionado el gráfico proceden de la consulta efectuada en el Archivo Beazley por "hallazgo" en enero de 2014. Cuando este aparece precisado con exactitud los centros que arrojan un mayor número de ejemplares en el Área del Mar Negro son Olbia, Phanagoria, Kerch, Apollonia Póntica y en menor medida Pichvnari. Llamamos imágenes "mixtas" a aquellas que sintetizan ambas leyendas en la reunión en una misma imagen de la cabeza de la Amazona, el prótomo de caballo y/o el de grifo. Para la cerámica ática en esta zona, Phanagoria: Morgan 2004; Apollonia Pontica: Panayotova et alii 2005.
} 


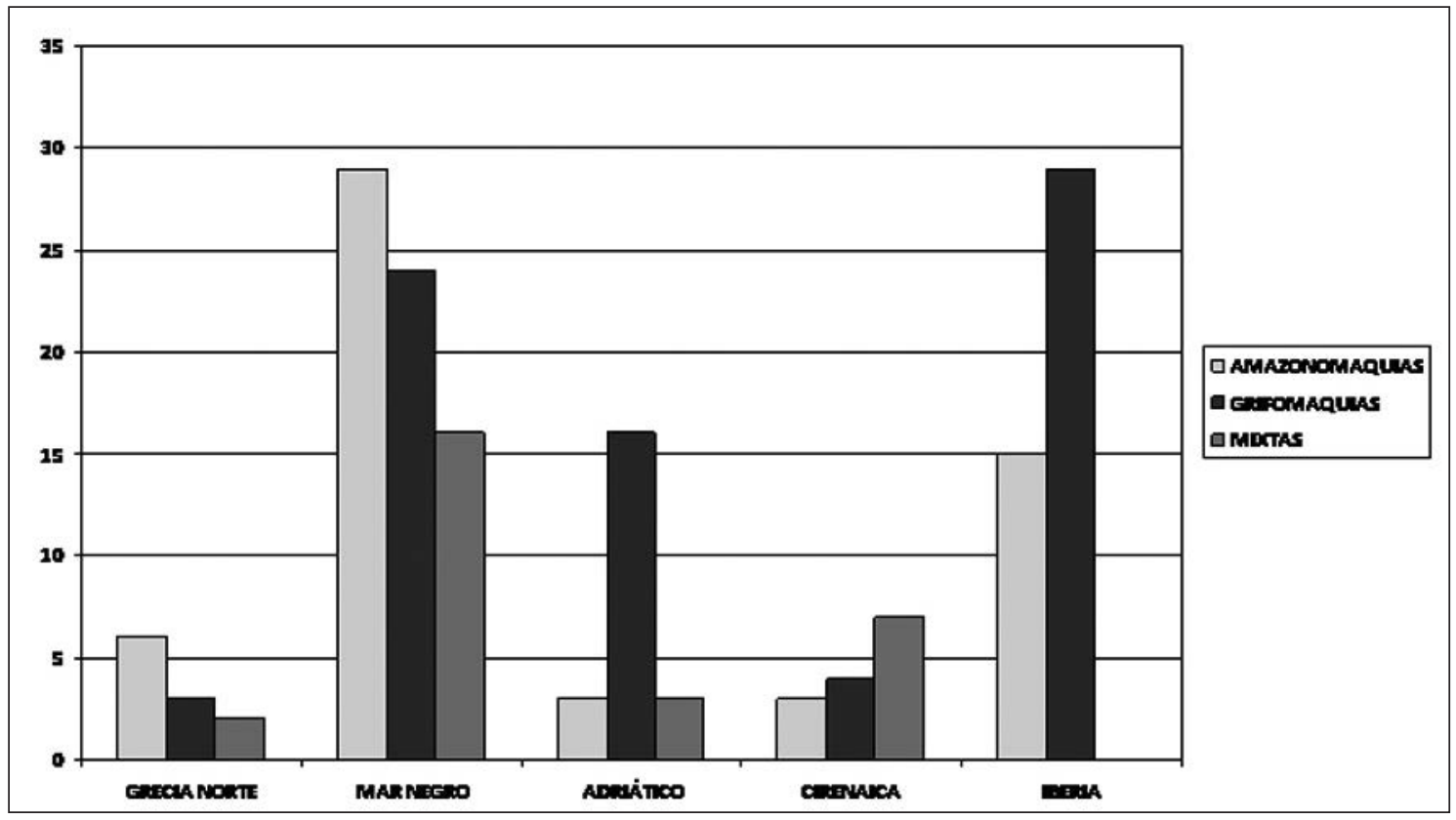

Figura 15. Gráfico con distribución de Amazonomaquias y Grifomaquias en el Mediterráneo.

\section{AMAZONAS, GRIFOS Y ARIMASPOS EN EL BÓSFORO}

El área del Mar Negro se hallaba cerca, al menos mentalmente, de la patria originaria de las Amazonas ¿Había un conocimiento real en el siglo IV a.C. en torno al Estrecho de Kerch de lo que la arqueología consigna como un hecho; la existencia de mujeres guerreras entre los pueblos nómadas escitas como lo ponen de manifiesto un buen número de tumbas femeninas? (Lebedynsky 2009). ¿Podrían explicar las extrañas costumbres de las célebres viudas de los escitas recogidas por Herodoto (IV, 110) de estas temidas oiorpata (asesinas de hombres) el interés por la representación de las Amazonas? No resulta fácil dar respuesta a ninguna de estas preguntas. En la medida en que las Amazonas son para los griegos una construcción mental y que forman parte de una cartografía simbólica, resultaría extremadamente peligroso establecer relaciones de causa a efecto, máxime si pensamos que estas representaciones no llegan de modo exclusivo al área del Mar Negro.

¿Ha de ser leída entonces esta presencia en clave de exotismo? Aunque es un aspecto a tener en cuenta, esta interpretación supone una cierta pasividad por parte de los receptores de las imágenes que cuadra mal, al menos en el caso que nos ocupa, con zonas donde los contactos culturales con el mundo griego continental son múltiples y prolongados en el tiem- po. Es un hecho que nos hallamos ante un mercado floreciente o, dicho de otra manera, que la ley de la oferta y la demanda funciona, lo que podría implicar, a nuestro parecer, un cierto grado de conocimiento de los gustos de la clientela griega del Mar Negro por parte de los ceramistas áticos. No hay que olvidar que estos productos estaban dirigidos fundamentalmente a las comunidades griegas coloniales y que solo en casos aislados llegaban a los territorios y pueblos limítrofes. Por otra parte y hasta donde se conocen los registros arqueológicos, un cierto número de vasos habría sido hallado en tumbas monumentales de tipo túmulo, características en origen de los pueblos escitas, tipo de enterramiento que podría haber sido adoptado por las élites del reino del Bósforo en el siglo IV a.C. Sería el caso entre otras de las tumbas de cámara de Juz Oba en las inmediaciones de Panticapea y Kekuvatsky donde aparecen pélices áticas. La importancia que cobró este tipo de vaso en esta zona y por extensión el tema de las Amazonas, no admite dudas, si tenemos en cuenta la existencia de las llamadas "pélices a la acuarela" o "Aquarellpeliken", imitaciones locales en técnica policromada con la temática de la de figuras rojas ática. Las pélices y quizá las imágenes que las adornan podrían funcionar como una especie de marcador cultural del reino del Bósforo en el siglo IV a.C. y como símbolo de estatus.

Sabemos por las fuentes que, desde fines del siglo v (en torno al 480 a.C.), las principales ciudades del 
Ponto a ambas orillas del estrecho de Kerch, conocido como el Bósforo cimerio, se han constituido en lo que se conoce como el Reino del Bósforo con capital en Panticapea. Es decir, frente a la pléyade de ciudades independientes se configura ahora un estado que para construir su identidad va a precisar de sus propias raíces míticas, de su pasado legendario, en esta ocasión aglutinante, puesto que todas ellas pasan a formar parte de la misma entidad política. Podríamos decir que la frontera de lo griego nace ahora más allá de los territorios que abarcaba la recién creada entidad política.

Quizá no sea disparatado pensar que los pintores áticos del siglo IV a.C., época de apogeo del Reino del Bósforo, hallaron una fórmula adecuada a esta nueva realidad reuniendo en un mismo vaso a modo de emblema lo que podría funcionar como símbolo de esos nuevos límites ${ }^{20}$. Así, las Amazonas y los grifos que siempre habían evolucionado de manera independiente se cargan ahora de un nuevo significado en una imagen sincrética. ¿Contaminación, exotismo, desconocimiento por parte de los pintores? Aún sin descartar categóricamente ninguna, es posible que estemos asistiendo a una nueva formulación del concepto de frontera, a una nueva construcción de la geografía del imaginario de la eschatia donde todo es posible, justo allí donde esta comienza (Beazley Archive 230463) (Fig. 16). Imagen que, por extensión, ha de servir para dibujar cualquier frontera.

En cuanto a las escenas de Grifomaquia, parece fácil también establecer la conexión entre la producción ateniense y las regiones del Mar Negro, que la mayoría de los autores antiguos consideraban la tierra de origen de los legendarios Arimaspos. Se ha sugerido (Metzger 1951: 332) que los pintores del Cerámico introdujeron en su repertorio la Grifomaquia porque este tipo de representación halagaba el gusto de la clientela de las colonias griegas del Mar Negro, o incluso de los pueblos indígenas ribereños, y que habría sido alentado en el siglo IV a.C. por las estrechas y fructíferas relaciones comerciales con esta región. Ello supondría que los compradores del Mar Negro identificaban la leyenda y a sus personajes como autóctonos, o no muy alejados, de la región en la que se producía la adquisición de los vasos decorados con estas imágenes. Sin embargo, y aunque los grifos pudieran tener una cierta popularidad, nunca hubo una tradición iconográfica entre los pueblos ribereños del Mar Negro, escitas o tracios, que representara este combate legendario (MacDonald 1987: 53-64). Situar

${ }^{20}$ Beazley Archive 230466. San Petersburgo, Hermitage KAB65E. Pélice ática de figuras rojas, atribuida al P. de la Amazona, hallada en el sur de Rusia, 400-300 a.C.

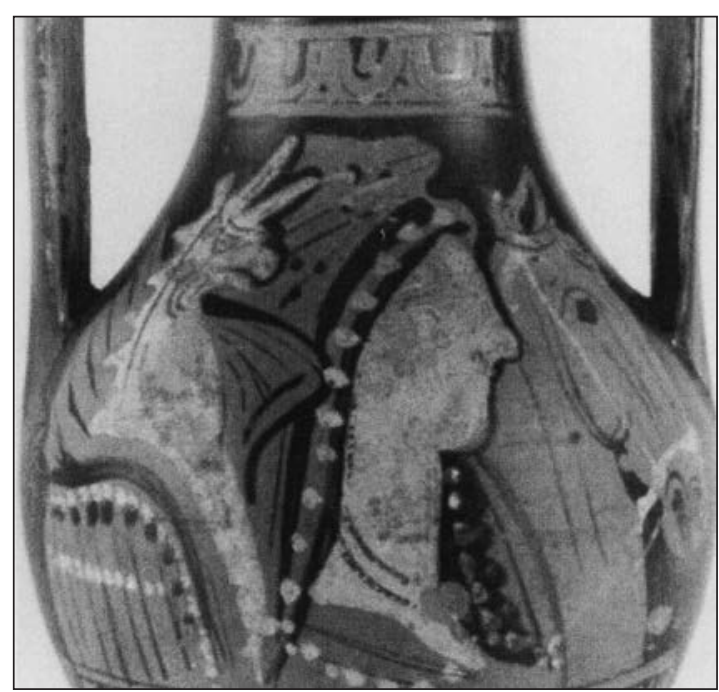

Figura 16. Pélice ática del Pintor de la Amazona, hallada en el sur de Rusia (400-350 a.C.). San Petersburgo, Hermitage ST2192. Fotografía: Beazley Archive 230463.

el mítico escenario de la Grifomaquia en la Europa nord-oriental podría justificar una posible demanda por parte de los colonos griegos allí asentados, que verían en ella una alusión idealizada a su propio entorno. Pero ello no explica su aparición en otras regiones del mundo conocido, precisamente y con abundancia, en otros límites de la oikoumene.

La razón por la que esta leyenda y sus imágenes tuvieron tan gran popularidad y fueron abundantemente comercializadas en áreas periféricas del Mediterráneo puede ser explicada en términos productivos y comerciales, pero también intervienen aquí otros aspectos ideológicos, como los fenómenos de definición identitaria de los griegos, de etnicidad, de representación del mundo, de sus límites y sus fronteras.

\section{AMAZONAS, GRIFOS Y ARIMASPOS EN IBE- RIA (CF. ANEXO I)}

Amazonomaquias y Grifomaquias no son escenas muy abundantes en los vasos áticos del siglo IV a.C. importados a la Península Ibérica, especialmente frente a las del mundo dionisíaco, el tema más popular y prolífico entre las importaciones griegas del extremo Occidente. Las imágenes de Amazonomaquias son las más antiguas, de la segunda mitad del siglo $\mathrm{v}^{21}$, mientras que las de Grifomaquias

\footnotetext{
${ }^{21}$ No incluimos en este estudio los vasos áticos de la segunda mitad del siglo $\mathrm{V}$ decorados con escenas de Amazonomaquias porque estamos analizando un fenómeno,
} 
no se documentan hasta el siglo IV a.C., cuando la frecuencia de aparición de ambas escenas sufra un espectacular aumento. Es entonces cuando salen fuera de Emporion, a la que se circunscriben los hallazgos del siglo anterior, y se localizan en otras regiones de la Península Ibérica, especialmente en Andalucía oriental, el entorno emporitano y, en menor medida, el Levante. Se documentan también en Baleares, en el Pecio de El Sec, pero la situación geográfica del lugar del naufragio del barco que transportaba estos vasos no debe hacernos olvidar que iban destinados con toda probabilidad a otra región de la Península Ibérica, quizás Andalucía o el Levante.

Las escenas de Amazonomaquias del siglo IV a.C. decoran con preferencia crateras de campana del Grupo de Telos y una pélice del estilo de Kerch. Con seguridad se puede identificar este tema en una cratera y en una pélice de Emporion (Miró 2006: $n^{\circ}$ 3066, 3226), en una cratera de la necrópolis de Galera (Sánchez 1992: no 148), dos de Toya (Sánchez 1992: no 396: 413) y otra de Baza (Sánchez 1992: no 28). Posiblemente haya más ejemplares entre los reunidos en el grupo intermedio, aquel que hemos denominado Amazonomaquias/Grifomaquias (Cf. Anexo I), pero el tamaño de los fragmentos nos impide distinguir a las Amazonas de los Arimaspos y asignar con seguridad estos vasos a una categoría iconográfica determinada. De los seis ejemplos registrados con escenas de Amazonomaquia, solo la cratera de Baza (Fig. 14) ofrece una narración explícita del enfrentamiento entre estas mujeres orientales y los guerreros griegos: ellas combaten montadas sobre sus caballos, mientras ellos, a pie, ocultan sus rostros tras grandes escudos redondos. El pintor ha destacado la alteridad de este encuentro, en el que todo está por decidir, aunque el ocultamiento del rostro de los griegos parece anunciar su derrota y aludir a la incertidumbre del destino de aquellos que, tras las Guerras del Peloponeso y el dominio macedónico, han perdido su libertad frente a un poder extranjero. Tres de las imágenes, de Emporion (Miró 2006: n 3226), Galera (Sánchez 1992: nº 148) y Toya (Sánchez 1992: no 413), resumen en los prótomos de caballo y en la cabeza de la Amazona, todo el universo legendario, narrativo e iconográfico, de este pueblo mítico de mujeres guerreras. Posiblemente la cratera de campana de Toya, de la que solo se conserva la imagen de un prótomo de caballo, recoja también este tema en su expresión sintetizada,

$\overline{\text { la construcción }}$ del imaginario de la frontera con este tipo de imágenes, característico del siglo IV a.C., y porque esos vasos forman parte de una dinámica productiva y comercial diferente. En todo caso, los vasos del siglo V con imágenes seguras de Amazonas se reducen a tres copas de Emporion (Miró 2006: nº 352 683, 937). por su similitud con la cratera de Galera, quizás obra del mismo pintor, a pesar de no haberse conservado la cabeza de la Amazona. En otro fragmento de Toya (Sánchez 1992: no 396), la carnación blanca del personaje oriental tocado con gorro frigio nos inclina a identificarla como este personaje mítico.

Imágenes de Amazonas pueden ser también las cabezas representadas en el interior de siete copas del Grupo de Viena 116 procedentes de El Sec (Arribas et alli 1987: $\mathrm{n}^{\circ}$ 62-66, 68, 69), en una de la calle Zacatín de Granada (Rambla 1999: fig. 4,4) y en una de Castellones de Ceal (Sánchez 1992: no 277), resumidas en una cabeza, ¿femenina?, tocada con gorro frigio. La ausencia de adornos - collar, pendientes - y de pintura blanca en sus carnaciones no nos permite asignarle una identificación segura, Arimaspo o Amazona, aunque la presencia en El Sec de copas del mismo Grupo decoradas con prótomos de grifo podría indicarnos que los pintores de este taller, cuando aluden sintéticamente a la Grifomaquia, lo hacen con la imagen del animal fabuloso, más que con la imagen del Arimaspo. Por ello, quizá sea posible identificar las cabezas tocadas con gorro frigio con las Amazonas, una imagen que resaltaría su atuendo oriental y, por tanto, su lejanía cultural y geográfica.

Las imágenes de Grifomaquias, más abundantes que las de Amazonomaquias, decoran crateras de campana del Grupo de Telos, copas del Grupo de Viena 116 y pélices del Grupo G y del estilo de Kerch. Solo se documenta un ejemplo de una lecane, también del Grupo de Viena 116, procedente de Roses (Puig y Martín 2006: fig. 6, 71). Las crateras permiten desplegar imágenes más complejas que las pélices o copas. En ellas se muestra el encarnizado combate entre los Arimaspos, montados a caballo, en carro o a pie, y los fabulosos grifos, siempre resaltados en blanco. En las pélices se opta por el esquema de los prótomos de grifo flanqueando la cabeza del Arimaspo, excepto en un ejemplar de Emporion (Miró 2006: nº 3179) y en otro de Roses (Puig y Martín 2006: fig. 6, 72, 7), donde se representa al menos a dos Arimaspos a pie en lucha, suponemos, con uno o dos grifos. En las copas, el pintor ha escogido la imagen del prótomo de grifo para decorar el medallón interior y resumir en un solo icono, poderoso, pregnante, la historia mítica y la alteridad del enfrentamiento entre un pueblo exótico y lejano y estos seres híbridos.

Nunca llegaron a Iberia las imágenes que hemos denominado 'mixtas', es decir, aquellas donde se funden en un solo relato visual ambos temas, expresado en la cabeza de la Amazona, el prótomo de caballo y/o el de grifo. Esta construcción amalgamada de lo exótico y de la alteridad estuvo destinada al Mar Negro, a la Cirenaica y, en menor medida, al Adriá- 
ANEXO I

Representaciones de Amazonomaquias y Grifomaquias en la Península Ibérica*

AMAZONOMAQUIAS

$\begin{array}{ccccc}\text { FORMA } & \text { PINTOR } & \text { FECHA } & \text { PERSONAJES } & \text { YACIMIENTO } \\ \text { Copa } & & 450-425 & \text { Amazona } & \text { Emporion, Neápolis } \\ \text { Copa } & & 425-400 & \text { Amazona contra griego } & \text { Emporion, Neápolis } \\ \text { Cratera campana } & & 400-375 & \text { Amazona } & \text { Emporion, Neápolis } \\ \text { Pélice } & \text { Estilo Kertch } & 350-325 & \text { Amazonas, prótomo caballo } & \text { Emporion, Neápolis } \\ \text { Cratera campana } & & 375-350 & \text { Amazona, prótomo caballo } & \text { Necrópolis de Galera } \\ \text { Cratera campana } & \text { York-Reverse G } & 375-350 & \text { Amazonas contra griegos } & \text { Baza }\end{array}$

BIBLIOGRAFÍA

Miró 2006, nº 937

Miró 2006, $\mathrm{n}^{\circ} 352$

Miró 2006, nº 3066

Miró 2006, n 3226

Sánchez $1992, \mathrm{n}^{\circ} 148$

Sánchez 1992, fig. 2

\section{AMAZONOMAQUIAS / GRIFOMAQUIAS}

$\begin{array}{ccc}\text { FORMA } & \text { PINTOR } & \text { FECHA } \\ \text { Ánfora } & & 450-425 \\ \text { Copa } & & 430-425 \\ \text { Copa } & & 425-400 \\ \text { Copa } & & 425-400 \\ \text { Enócoe } & & 425-400 \\ \text { Cratera campana } & & 400-350 \\ \text { Cratera campana } & \text { Estilo Kertch } & 400-350 \\ \text { Copa } & \text { Viena 116 G } & 375-350 \\ \text { Copa } & \text { Viena 116 G } & 375-350 \\ \text { Copa } & \text { Viena 116 G } & 375-350 \\ \text { Copa } & \text { Viena 116 G } & 375-350 \\ \text { Copa } & \text { Viena 116 G } & 375-350 \\ \text { Copa } & \text { Viena 116 G } & 375-350 \\ \text { Copa } & \text { Viena 116 G } & 375-350 \\ \text { Cratera campana } & & 400-350 \\ \text { Cratera campana } & & 400-375 \\ \text { Copa } & \text { Viena 116 G } & 375-350 \\ \text { Copa } & \text { Viena } 116 \mathrm{G} & 375-350 \\ \text { Cratera campana } & & 375-350\end{array}$

PERSONAJES
Oriental
Oriental
Oriental a caballo
Oriental
Oriental
Oriental a caballo
Oriental
Oriental, cabeza
Oriental, cabeza
Oriental, cabeza
Oriental, cabeza
Oriental, cabeza
Oriental, cabeza
Oriental, cabeza
Oriental, cabeza
Caballo, prótomo
Oriental, cabeza
Oriental, cabeza
Oriental

\section{GRIFOMAQUIAS}

$\begin{array}{ccc}\text { FORMA } & \text { PINTOR } & \text { FECHA } \\ \text { Pélice } & & 400-350 \\ \text { Pélice } & \text { Estilo Kertch } & 400-350 \\ \text { Cratera campana } & & 400-375 \\ \text { Copa } & \text { Estilo Kertch } & 375-350 \\ \text { Lecane } & \text { Viena 116 G } & 375-350 \\ \text { Cratera campana } & & 400-350 \\ \text { Cratera campana } & & 400-350 \\ \text { Cratera campana } & \text { P. Amazona } & 375-350 \\ \text { Copa } & \text { Viena 116 G } & 375-350 \\ \text { Copa } & \text { Viena 116 G } & 375-350 \\ \text { Copa } & \text { Viena 116 G } & 375-350 \\ \text { Copa } & \text { Viena 116 G } & 375-350 \\ \text { Copa } & \text { Viena 116 G } & 375-350 \\ \text { Copa } & \text { Viena 116 G } & 375-350 \\ \text { Cratera campana } & \text { Grifomaquia Oxford } & 375-350 \\ \text { Cratera campana } & & 400-350 \\ \text { Cratera campana } & & 400-350 \\ \text { Cratera campana } & & 400-350 \\ \text { Pélice } & & 400-375 \\ \text { Cratera campana } & & 400-350 \\ \text { Cratera campana } & & 400-350 \\ \text { Cratera campana } & & 400-350 \\ \text { Pélice } & \text { Estilo Kertch } & 350-325 \\ \text { Copa } & \text { Viena 116 G } & 375-350 \\ \text { Cratera campana } & \text { Grifomaquia Oxford } & 375-350 \\ \text { Cratera campana } & \text { Bizco } & 375-350 \\ \text { Copa } & \text { Viena 116 G } & 375-350\end{array}$

PERSONA

Arimaspos

Grifo

Grifo
Grifo

Grifo

Grifo

Grifo

Arimaspo

Arimaspos, grifos

Grifo, prótomo

Grifo, prótomo

Grifo, prótomo

Grifo, prótomo

Grifo, prótomo

Arimaspo

Arimaspos, grifos

Arimaspos, grifos

Arimaspo, grifo

$$
\text { Grifo }
$$

Grifo

Arimaspo, grifo

Arimaspo, grifo

Arimaspo, grifo

Arimaspo, grifos, prótomos

Grifo, prótomo

Arimaspos, Grifos

Arimaspos, grifos

Grifo, prótomo

\author{
YACIMIENTO \\ Emporion, Neápolis \\ Emporion, Neápolis \\ Emporion, Neápolis \\ Emporion, Neápolis \\ Emporion, Neápolis \\ Les Guardies, Tarragona \\ Molí d'Espigol \\ Pecio El Sec \\ Pecio El Sec \\ Pecio El Sec \\ Pecio El Sec \\ Pecio El Sec \\ Pecio El Sec \\ Pecio El Sec \\ Toya \\ Toya \\ Castellones de Ceal \\ Granada, c/ Zacatín 10 \\ Galera
}

BIBLIOGRAFÍA

Miró 2006, no 3235

Miró 2006, no 248

Miró 2006, $\mathrm{n}^{\circ} 355$

Miró 2006, n 357

Miró 2006, $\mathrm{n}^{\circ} 3253$

Morer/Rigo 1999, 52

Cura 2006, fig. 86-5

Arribas 1987, $\mathrm{n}^{\circ} 62$

Arribas 1987, $\mathrm{n}^{\circ} 63$

Arribas 1987, $\mathrm{n}^{\circ} 64$

Arribas 1987, $\mathrm{n}^{\circ} 65$

Arribas 1987, no 66

Arribas 1987, $\mathrm{n}^{\circ} 68$

Arribas 1987, n 69

Sánchez 1992, nº 396

Sánchez 1992, nº 413

Sánchez 1992, no 227

Rambla 1999, fig.4,4

Sánchez 1992, n 122

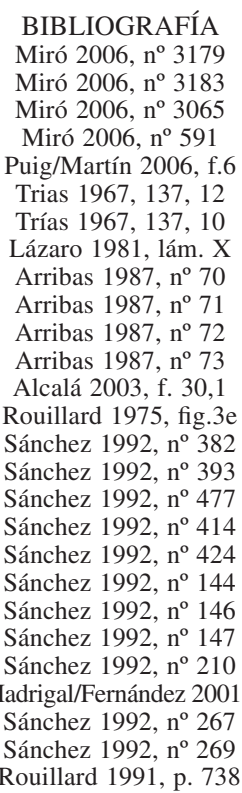

${ }^{*}$ Los datos están extraídos de la base de datos Iberia Graeca: http://www.iberiagraeca.net/base/. Debemos advertir que dicha base de datos está actualmente en construcción y que no están recogidos los yacimientos y hallazgos de todas las Comunidades Autónomas. Se han completado con obras de referencia, especialmente Trias 1967, Sánchez 1992 y Rouillard 1991. 
tico, quizás porque la imagen humana predominante, la de la Amazona, no tuvo mucha aceptación entre la clientela occidental o, sencillamente, porque se representan mayoritariamente sobre pélices ${ }^{22}$, una forma apenas demandada por los iberos ni integrada, excepto en el caso de Galera, en sus rituales funerarios. Los iberos prefieren las crateras de campana para utilizarlas como urnas cinerarias, mientras que en las sociedades indígenas del Mar Negro, por los datos hoy conocidos, utilizan las pélices para ese fin en lugar de las crateras.

¿Cómo explicar la mayor abundancia de escenas de Grifomaquia $^{23}$ en la Península Ibérica? Existe un dato determinante, que es la preferencia de los pintores del Grupo G y del Grupo de Viena 116 por decorar con este tema las pélices y algunas de las copas. También los pintores del Grupo de Telos decoran algunas de sus crateras con él, aunque no preferentemente. Si los talleres que exportan esta amplia producción de crateras, pélices y copas tienen preferencia por determinadas formas, decoradas con determinadas escenas, el fenómeno se explicaría como una cuestión comercial. Pero, ¿cómo explicarlo frente a otras regiones en las que son más abundantes las escenas de Amazonomaquias?

La presencia de determinados vasos e imágenes está determinada por mecanismos económicos y comerciales que pueden influir en la ausencia, abundancia o escasez de algunos elementos. El productor puede restringir o seleccionar un determinado tipo de vaso y las imágenes que le acompañan, destinarlo fundamentalmente al mercado local. En las creaciones específicamente dirigidas a mercados exteriores pueden funcionar construcciones mentales muy determinadas (cf. lo dicho en relación con el mundo póntico). De todas formas, hoy en día se acepta, cada vez en mayor medida, una selección consciente de vasos e imágenes por parte de los compradores de mercados remotos,

${ }^{22}$ En los listados del Beazley Archive Database, estas escenas "mixtas" se documentan en 21 pélices (12 del Grupo G, 5 del Pintor de la Amazona y 4 sin atribuir), y en 7 crateras de campana (1 del Grupo G, 1 del Pintor de la Amazona, 2 del Pintor de Kerch, 1 del Pintor de Filottrano y 2 sin atribuir).

${ }^{23} \mathrm{Cf}$. Anexo I. Se documentan 29 ejemplos de Grifomaquias frente a 6 seguros de Amazonomaquias. Si añadimos a este último grupo las copas de El Sec, de Calle Zacatín y de Castellones de Ceal con cabezas orientales, serán 29 frente a 15. Al incluir los vasos con estas representaciones hallados en el Sur de Francia, que forman parte del mismo circuito comercial, al menos de Emporion, vemos que se documentan tres crateras de campana del Pintor de Kerch en Enserune (Beazley Archive n 11204, 218266, 230475 ), y una hidria y una pélice, también del Pintor de Kerch, en Marsella (Beazley Archive $n^{\circ}$ 4397, 43432). De estas cinco piezas, tres están decoradas con Amazonomaquias y dos con Grifomaquias. Sumándolas a las de la Península Ibérica resultaría un total de 31 Grifomaquias frente a 18 Amazonomaquias. de tal forma que sus demandas pueden incluso llegar a configurar en cierta medida la producción de algún taller (Sánchez 1992; Sánchez 2000).

La demanda o aceptación de imágenes de Amazonomaquias fue bastante restringida en Iberia en comparación con la del mundo póntico, quizás porque estas escenas no tenían aquí el mismo valor que el que tuvieron allí, donde, como hemos visto, fueron utilizadas en la reafirmación de las estrategias de definición identitaria, donde identificaban esta leyenda y a sus personajes como autóctonos, o no muy alejados de la región en la que se producía la adquisición de los vasos decorados con estas imágenes. Lo significativo en Iberia es que, dentro de su escasez, las Amazonas son más abundantes en el ámbito de Emporion (si contamos también con las de la segunda mitad del siglo $\mathrm{V}$ a.C.) y de su entorno más inmediato, es decir, en el ámbito colonial que entre las sociedades ibéricas. Quizás en Emporion se utilizaron como elemento cultural significativo en la construcción de la identidad colonial como opuesta a la de "los otros", los "bárbaros" ibéricos. En las estrategias de afirmación de las identidades sociales no solo son imprescindibles las imágenes modélicas. Quizás más necesarias aún que estas sean las que representan su contramodelo. Frente a la mujer socializada, las mujeres míticas que representan la alteridad y la oposición absoluta a las normas de la convivencia ordenada y civilizada y que ilustran en mayor medida que aquélla la ansiedad y el temor masculino ante la naturaleza femenina, salvaje e incontrolable. Las Amazonas son especialmente importantes en esta estrategia asertiva masculina, pues podrían ilustrar la misma actitud frente a las potenciales amenazas que esta figura encarna, -mujer, salvaje y bárbara-, y más aún en este contexto colonial, enfrentado a dinámicas de interacción con el mundo indígena. La abundancia en términos relativos de imágenes de Amazonas en Emporion puede ser un signo y una respuesta ante esta situación. Pero para aceptar esta propuesta, debemos partir de la hipótesis de que este hecho es significativo y no aleatorio, no explicable única y exclusivamente por mecanismos y circunstancias productivas o comerciales, que los ampuritanos eligen y seleccionan conscientemente estas imágenes, posiblemente en situaciones de estrés o ansiedad en el flujo de información e interacción entre ambos mundos (Cabrera 2000). Las escenas de Amazonomaquias podrían, además, reflejar esa interacción, es decir, los ampuritanos podrían identificarse con los "griegos" en su enfrentamiento con las extrañas y extranjeras Amazonas, que personificarían la alteridad del mundo, tan próximo, que les rodea. Las fronteras están trazadas en este caso a las mismas puertas de la ciudad. 
En el caso de las imágenes de Grifomaquias, mucho más numerosas que las anteriores no solo en Iberia sino en el Adriático y en Cirenaica, podemos aducir una explicación al margen de las razones productivas y comerciales. En Iberia, el combate singular entre un hombre -héroe o dios es difícil de determinar- y un grifo no era en absoluto una imagen extraña a su mundo y a su imaginario, está presente ya desde el siglo VII en los marfiles fenicios del Bajo Guadalquivir (Vidal de Brant 1973), o más recientemente, en la magnífica Grifomaquia ibérica de Porcuna (Negueruela 1990: 255-257), o en tantas imágenes de grifos aislados en esculturas, cajas cinerarias de piedra, joyas o vasos ibéricos. El tema de las Amazonas es más problemático, pues no hay ninguna tradición iconográfica de mujeres guerreras en el ámbito peninsular. De hecho, como ya hemos señalado, de los dos temas, el que tuvo más éxito fue, sin duda, la Grifomaquia, porque ya formaba parte de su universo mítico y de su repertorio iconográfico, revestido de un significado ligado a la concepción del poder, de la acción civilizadora de un héroe fundador de linajes, de la conquista de un territorio hostil o del agón como acción iniciática (Olmos 2002: 111). La inclusión casi sistemática de la imagen ática en contextos funerarios refuerza esta interpretación, pues en la muerte ibérica, el agón, el enfrentamiento con el monstruo tiene un sentido heroizador, es acción iniciática que reproduce la conflagración de las fuerzas vitales, cósmicas, de la naturaleza, siempre en permanente lucha para dar a luz el devenir. En el agón final de la vida, traspasada ya la frontera de la muerte, el hombre se transforma en héroe, adquiere en el combate contra el ser sobrenatural la aristeia que confirmará su honor, la gloria de su linaje, y le concederá la inmortalidad. Por otro lado, la imagen icónica del grifo apotropaico dibuja el espacio y la geografía de la muerte, la última frontera, el territorio de la eschatiá por excelencia. El monstruo híbrido aterroriza al tiempo que protege, es guardián de tumbas, del difunto y de su tránsito al allende, pues su naturaleza diversa le permite transitar espacios diferentes, cruzar los límites, acompañar al hombre en su último viaje (Olmos 1996). Hubiera o no una demanda real por parte de los clientes ibéricos de las escenas de Grifomaquias y de los grifos, a su llegada a Iberia estas imágenes se integrarían perfectamente, quizás mejor que la de las Amazonas, en su universo simbólico bajo una lectura funeraria y trascendente.

\section{LAS FRONTERAS Y SUS IMÁGENES}

La construcción mental del espacio griego está íntimamente ligada a la definición de su identidad: lo que es griego frente a lo que no lo es. Situado frente al mundo, el varón se define a sí mismo en oposición a "lo que no es", a "lo otro". El Mismo no se puede concebir ni definir si no es en relación al Otro, a la multiplicidad de los otros (Vernant 1985: 24-28). El modelo es el espacio de la cultura, de las tierras cultivadas, de la civilización, de la polis y del varón. Es el espacio ciudadano, donde los hombres y sus relaciones sociales, políticas y económicas, se rigen por normas, donde se practican la piedad hacia los dioses, los rituales religiosos codificados y la hospitalidad incluso ante el xenos, el extranjero, el que no pertenece a nuestro mundo sino al de los otros. El contramodelo es el espacio de lo incivilizado, lo salvaje, de la naturaleza, de la mujer. Es el espacio de "los otros", de los que no pertenecen a la cultura o a la naturaleza de aquel que define, construido para explicar, ordenar, y dar sentido al hombre y al cosmos.

$\mathrm{El}$ acto fundamental con el que los griegos definieron el mundo fue otorgarle límites, crear sus fronteras, marcar la línea divisoria que lo separaba de lo indefinido. Sin esos límites, tierra y mar no serían sino apeiron, algo indefinido, contrario al orden, al cosmos que debe ser el mundo habitado (Romm 1994: 1113). Los confines son un constructo concebido en el sentido más vago y amplio, pues representan el límite del mundo humano, son regiones extremadamente remotas y extensas. En su representación geométrica, el mundo es una superficie circular, plana, rodeada por la corriente del Océano que ciñe la Tierra. Los confines del mundo, situados junto a la corriente del Océano, prolongan y enriquecen la alteridad de la eschatiá. Son la antesala del Hades, de los paraísos -los Campos Elíseos, el Jardín de las Hespérides, la Isla Blanca-, de regiones donde viven pueblos ideales, como los Hiperbóreos, los Feacios, los Bienaventurados, Etíopes o Indios en una perpetua Edad de Oro (Cambron-Goulet 2007), un lugar ideal caracterizado por una relación privilegiada con lo divino, por la abundancia de bienes y riquezas ${ }^{24}$, por la ausencia de sufrimiento y de vejez, o por una sociedad igualitaria.

En la construcción espacial y antropológica de los confines y de la eschatiá, conviven igualmente los rasgos ideales, positivos, con los negativos. Pero tanto unos como otros son extraños, ajenos, ambos están igualmente impregnados de alteridad, en la frontera entre lo humano y lo divino o, por el contrario, lo humano y lo animal, revestidos de trazos monstruosos e inquietantes, más allá de los límites de la humani-

\footnotetext{
${ }^{24}$ Herodoto III, 116: “...parece ser que las zonas más remotas del mundo (eschatiai), que circundan el resto de la tierra y delimitan su extensión, poseen fundamentalmente los productos que a nosotros se nos antojan más preciosos y más raros".
} 
dad. Los griegos construyen así toda una geografía de los confines a partir de un centro, Grecia. Los pueblos del fin del mundo (Cambron-Goulet 2007) se localizan imprecisamente en cuatro zonas de la eschatiá, siguiendo los puntos cardinales: al norte, los Hiperbóreos, al este, los Indios, al sur los Etíopes, y al oeste, los Bienaventurados. Junto a ellos, algo más cercanos geográficamente, pero igualmente alejados conceptualmente, están otros pueblos míticos o reales, pero vistos siempre bajo la óptica griega que hace de ellos pueblos legendarios, como los Feacios, los Isedones, los Cimerios, las Amazonas o los Arimaspos.

La frontera, o las fronteras, que separan la oikoumene de la eschatiá se definen a través de las zonas limítrofes donde el Otro se manifiesta en el contacto que se mantiene regularmente con él, donde salvaje y civilizado se codean, para oponerse, pero también para interactuar. Esa frontera (Hartog 1996: 13 y ss.) entre ambos mundos, espacio ambiguo, extraño, peligroso, territorio de la violencia y la transgresión, fue imaginado por los griegos a través de innumerables mitos e imágenes. Es el paisaje de la montaña, del mar, del oriente hostil, del remoto norte y del lejano occidente, un mundo poblado por fieras, monstruos, salvajes, bárbaros, transitado por héroes y dioses. Sus parajes esconden los peligros de la alteridad, donde solo el héroe que se adentra en el territorio hostil de la barbarie y de la naturaleza salvaje puede salir triunfante.

Relatos, desde el primero, inaugural, de Ulises (Hartog 1996: 13), e imágenes van creando a lo largo de los siglos los contornos de la identidad griega, del mundo conocido y de sus confines, de la eschatiá. Sus protagonistas trazan las fronteras, las traspasan y experimentan. La leyenda de las Amazonas y de los Arimaspos y su perpetuo combate contra los grifos son otros de esos relatos e imágenes que son ventana abierta a los confines del mundo y a la construcción de la identidad griega, la imagen del Otro por excelencia, de aquellos que no son humanos, sino monstruos, salvajes y bárbaros, que representan una amenaza o, simplemente, lo exótico y fabuloso.

El paisaje de la alteridad no fue siempre uniforme. El conocimiento geográfico y el contacto con otras culturas fueron alterando y enriqueciendo el discurso de la identidad griega. Como ya hemos señalado, tras las Guerras Médicas quedó en gran medida polarizado en la imagen del persa, que proporcionó un rostro conocido al Otro (MacDonald 1987: 70; Hartog 1996: 114). El bárbaro será ante todo el oriental. Y muchos otros pueblos que ejemplifican la alteridad serán representados a la manera oriental, a lo que contribuye su mítica localización en un Oriente mal definido e impreciso. En este sentido, las Amazonas siguen siendo marcadores de los límites hasta el punto de encarnar la más compleja construcción de lo que se puede encontrar un griego al otro lado de la delicada linde que separa la oikumene de la eschatiá, una sociedad de valerosas mujeres guerreras que viven al margen de los hombres y que ahora, en el siglo IV a.C., se ven asociar a uno de los seres más fabulosos jamás imaginados, los grifos, creando así una de las imágenes más perfectas al otro lado del espejo que concibieron los griegos para hablarnos de si mismos.

Grifomaquias y Amazonomaquias son imágenes que contribuyen a trazar los límites del mundo, a dibujar la eschatiá y sus fronteras. Que se exportaran a las regiones reales de la eschatiá griega -Mar Negro, Adriático, Cirenaica o Iberia- no quiere decir que los pintores necesariamente situaran allí a estos seres míticos y a sus acciones. Lo que indica es que con la elección de esas imágenes de frontera para zonas de frontera los pintores trazaban los límites de su propia concepción del mundo, de la oikoumene.

Otra cuestión es si hubo una demanda efectiva, real, por parte de los clientes de la frontera, si escitas, adriáticos, cirenaicos o iberos eligieron conscientemente esas imágenes con las que podrían sentirse identificados. La respuesta no es fácil. Quizás hubiera una demanda real ibérica —o escita, cirenaica o adrática- de estas imágenes, pero ello no quiere decir que los pintores del Cerámico las representaran pensando solo en satisfacer una demanda tan particular. Las imágenes de Grifomaquias y Amazonomaquias podían cristalizar una serie de conceptos y nociones, como la barbarie, la riqueza, lo fabuloso y prodigioso, y ser una manera de aprehender tierras lejanas situadas en los extremos del mundo. Con ellas enviaban a la frontera lo que definía a la frontera, y con ellas contribuían a ordenar y poner límites a su mundo por oposición a lo que está más allá de él, en los confines.

Las imágenes de frontera, insertas en mecanismos comerciales, en dinámicas de oferta y demanda que no agotan o esclerotizan su sentido, son para el mundo griego ante todo elementos indispensables en el juego de la identidad, en la construcción de la alteridad, de una antropología poética que es un paradigma de larga duración, revisado, ampliado o criticado, pero necesario para comprender el mundo, para habitarlo y hacer de él un mundo "humano", es decir, griego.

\section{BIBLIOGRAFÍA}

AAVV. 2002: Nymphea. Confin de la oikoumene. Fondos arqueológicos del Ermitage, Catálogo de la Exposición. (abreviado en Catálogo Nymphea). Alcalá-Zamora, L. 2003: La Necrópolis ibérica de 
Pozo Moro, Bibliotheca Archaeologica Hispana 23, Madrid.

Arribas, A., Trias, G. Cerdá, D. y de Hoz, J, 1987: El barco de El Sec (Costa de Claviá, Mallorca). Estudio de los materiales, Calvià.

Badinou, P. 2003: La laine et le parfum. Epinetra et alabastres, forme, iconographie et fonction, Louvain.

BAD $=$ Beazley Archive Database: http://www.beazley.ox.ac.uk

Benson, C. 1995: "Untamed Women. Amazons", E. D. Reeder (ed.), Pandora. Women in Classical Greece, Princeton, 373-380.

Bernabé, A. 1979: Fragmentos de épica griega arcaica, Madrid.

Beazley, J. D. 1963: Attic Red-Figure Vase-Painters (ARV2), Oxford.

Boardman, J. 1982: "Herakles, Theseus and Amazons", D. Kurtz y B. Sparkes (eds.), The Eye of Greece. Studies in the Art of Athens, Cambridge, 1-28.

Bothmer, D. Von 1957: Amazons in Greek Art, Oxford.

Bouzek, J. 1989: "Athènes et la Mer Noire", Bulletin de Correspondance Hellénique 113, 1, 249-259.

Braccesi, L. y Luni, M. (coords.) 2004: I Greci in Adriatico 2, Hesperia 18, Roma.

Buravčuk, O. E. 2010: "C Red-figured pottery", N. A. Lejpunskaja, Guldager Bilde, P., M. Hojte, V. V. Kaprivina y S. Kryzickij (eds.), The Lower City of Olbia (Sector NGS) in the 6th Century $B C$ to the 4th century AD, Black Sea Studies 13, Aarhus, 171-184.

Cabrera, P. 2000: "Las identidades peligrosas. La imagen de la mujer en Emporion a través de la iconografía cerámica", P. González (coord.), Espacios de género en Arqueología. Arqueología Espacial 22, 123-142.

Cabrera, P. y Rouillard, P. 2004: "El Grupo de Telos, pintores atenienses de mediados del siglo IV a.C.", El vaso griego y sus destinos, Catálogo de la Exposición celebrada en el Museo Arqueológico Nacional (diciembre 2004-febrero 2005), Madrid, 91-98.

Cambron-Goulet, M. 2007: Les étrangers des confins et le mythe de l'Âge d'Or: rencontre de l'idéal et du monstrueux dans la pensée grecque antique, Montréal.

Castriota, D. 2000: “Justice, Kingship and Imperialism: Rhetoric and Reality in Fifth-Century B.C. Representations following the Persian War", Not the Classical Ideal. Athens and the Construction of the Other in Greek Art, Leiden-Boston-Köln, 443-479.

Cura, M. 2006: El jaciment del Molí d'Espígol (Tornabous-Urgell). Excavacions arqueològiques $1987-$ 1992, Monografies 7, Barcelona.
D’Ercole, M. C. 2009: “Arimaspes et griffons, de la Mer Noire à l'Adriatique via Athènes", Mètis N. S. 7, 203-225.

Devambez, P. 1981: s.v. “Amazones", Lexicon Iconographicon Mythologiae Classicae I, Artemis Verlag, Zürich, 586-653.

Fornasier, J. 2007: Amazonen. Frauen, Kämpferinnen und Städtgründerinnen, Mainz am Rhein.

Giuman, M. 2002: "Il cinto della regina. Eracle e Ippolita: esegesi di un episodio mitico trarito e funzione", Iconografia 2001. Studi sull'immagine. Atti del Convegno (Padova, 30 maggio-1 giugno 2001) Padova, 225-237.

Giuman, M. 2006: "Il filo e le briglie. Epinetra, stoffe e Amazzoni tra mito e archeologia", F. H. MassaPairault (ed.), L'image antique et son interprétation. Collection de l'École Française de Rome 371, Roma, 237-259.

Gorbounova, X. 1997: s.v. "Arimaspoi”, Lexicon Iconographicum Mythologiae Classicae, vol. VIII, 1, Artemis Verlag, Zürich, 529-534.

Hartog, F. 1996: Mémoire d'Ulysse. Récits sur la frontière en Grèce ancienne, Paris.

Hermary, A. 2012: "Céramiques à figures rouges d'Apollonia du Pont, découvertes anciennes et récentes", G. R. Tsetskhladze (ed.), From the Pillars of Hercules to the Footsteps of the Argonauts. Colloquia Antiqua 4, 239-244.

Landolfini, M. (ed.) 2000: Adriatico tra IV e III sec. a.C. Vasi alto-adriatici tra Piceno, Spina e Adria. Atti del Convengo di Studi (Ancona, 1997), Roma.

Landolfi, M. 2000: "Il Pittore di Filottrano e la tarda ceramica attica a figure rose nel Piceno", B. Sabattini (ed.), La céramique attique du IVe siècle en Méditerranée Occidentale, Actes du Colloque international organisé par le Centre Camille Jullian, (Arles, 7-9 décembre 1995), Collection du Centre Jean Bérard 19, Naples, 77-91.

Lázaro Mengod, A. Mesado Oliver, N., Aranegui Gascó, C. y Fletcher Valls, D. 1981: Materiales de la necrópolis ibérica de Orleyl (Val d'Uxó, Castellón), Serie Trabajos Varios 70, Valencia.

Lebedynsky, I. 2009: Les Amazones: mythe et réalité des femmes guerrières chez les anciens nomades de la steppe, Paris.

Leduc, G. (dir.) 2008: Réalité et représentation des Amazones, Paris.

Lissarrague, Fr. y Schmitt-Pantel, P. 2008: "Amazones, entre peur et rêve", Leduc, G. (dir.), Réalité et représentation des Amazones, Paris, 43-64.

MacDonald, K. 1987: The Grypomachy in fourthcentury Attic Vase-Painting, Ontario.

Madrigal, A. y Fernández Rodríguez, M. 2001: "La necrópolis ibérica del Camino del Matadero (Al- 
hambra, Ciudad Real)", Arqueología funeraria: las necrópolis de incineración, Universidad de Castilla-La Mancha, Cuenca, 225-258.

Metzger, H. 1951: Les représentations dans la céramique attique du IVe siècle, BEFAR 172, Paris.

Miró, M. 2006: La ceràmica àtica de figures roges de la ciutat grega d'Empòrion, Monografies Emporitanes 14, Barcelona.

Morer, J. y Rigo, A. 1999: Ferro i ferrers en el món ibèric. El poblat de les Guàrdies (El Vendrell), Barcelona.

Morgan, C. 2004: Attic Fine Pottery of the Archaic to Hellenistic Periods in Phanagoria, Phanagoria Studies Volume 1. Colloquia Pontica volume 10, Leiden-Boston.

Negueruela, I. 1990: Los monumentos escultóricos ibéricos del Cerrillo Blanco de Porcuna (Jaén), Madrid.

Olmos, R. 1996: "Caminos escondidos. Imaginarios del espacio en la muerte ibérica", Homenaje al Prof. Manuel Fernández-Miranda, Complutum extra 6, 2, Madrid, 167-176.

Olmos, R. 2002: "Los grupos escultóricos del Cerrillo Blanco de Porcuna (Jaén). Un ensayo de lectura iconográfica convergente", Archivo Español de Arqueología 75, 107-122.

Panayotova, K., Riapov, A. y Baralis, A. 2005: "Les fouilles franco-bulgares de la nécropole classique et hellénistique d'Apollonia du Pont (2002-2004) : résultats préliminaires", Pontica, 95-121.

Papuci-Wladyka, E., Redina, E. F. y Machowski, W. 2008: Between Olbia and Odessa. Archaeological Research of the Greek Settlement at Koshary on the Black Sea (1998-2008), Kraków.

Petersen J. H. 2010: Cultural Interactions and Social Strategies on the Pontic Shores: Burial Customs in the Northern Black Sea Area c. 550-270 BC, Black Sea Studies 12, Aarhus.

Puig, A. M. y Martín, A. 2006: La colonia grega de Rhode (Roses, Alt Empordà), Sèrie Monogràfica 23, Girona.

Rambla, J. A. y Salado, J. B. 1999: "Hallazgos de época ibérica y musulmana junto a la Alcaicería de Granada", Anuario Arqueológico de Andalucía, Sevilla, 175-185.

Romm, J. S. 1994: The Edges of the Hearth in Ancient Thought. Geography, Exploration and Fiction, Princeton.

Roscino, C. 2011: "No Man's Land. Amazzonomachie nella prima ceramografia apula tramito e símbolo", C. Masseria, y D. Loscalzo (eds.), Miti di guerra, riti di pace. La guerra e la pace: un confronto interdisciplinare, Bari, 203-214.

Rouillard, P. 1975: "Les coupes attiques à figures rouges du IVème siècle en Andalousie", Mélanges de la Casa de Velázquez XI, Paris, 21-49.

Rouillard, P. 1991: Les Grecs et la Péninsule Ibérique du VIIIe au IVe siècle avant Jésus-Christ, Mélanges de la Casa de Velázquez, Paris.

Sánchez, C. 1992: El comercio de productos griegos en Andalucía Oriental. Siglos V-IV a.C. Estudio tipológico e iconográfico de la cerámica, Universidad Complutense de Madrid, Col. tesis doctorales $\mathrm{n}^{\circ}$ 1495/92, Madrid.

Sánchez, C. 2000: "Los pintores del Grupo de Telos", B. Sabattini (ed.), La céramique attique du IVe siècle en Méditerranée Occidentale, Actes du Colloque international organisé par le Centre Camille Jullian (Arles, 7-9 décembre 1995), Collection du Centre Jean Bérard 19, Naples, 35-46.

Toso, S. 2002: "Le cattive ragazze. Le Amazzoni, Onfale e Medea", I. Colpo, I. Favaretto, F. Ghedini (eds.), Iconografia 2001. Studi sull'immagine. Atti del Convegno (Padova, 30 maggio-1 giugno 2001) Padova, 289-307.

Trías de Arribas, G. 1967-1968: Cerámicas griegas de la Península Ibérica, Valencia.

Vernant, J. P. 1985: La mort dans les yeux. Figures de l'Autre en Grèce ancienne, Paris.

Vidal de Brant, M. 1973: "La iconografía del grifo en la Península Ibérica", Pyrenae 9, 7-151.

Recibido: 10-03-2014 Aceptado: 24-04-2014 